\title{
Metagenomic analysis of nitrogen and methane cycling in the Arabian Sea oxygen minimum zone
}

Claudia Lüke, Daan R. Speth, Martine A.R. Kox, Laura Villanueva, Mike S.M. Jetten

Oxygen minimum zones (OMZ) are areas in the global ocean where oxygen concentrations drop to below one percent. Low oxygen concentrations allow alternative respiration with nitrate and nitrite as electron acceptor to become prevalent in these areas, making them main contributors to oceanic nitrogen loss. The contribution of anammox and denitrification to nitrogen loss seems to vary in different OMZs. In the Arabian Sea, both processes were reported. Here, we performed a metagenomics study of the upper and core zone of the Arabian Sea OMZ, to provide a comprehensive overview of the genetic potential for nitrogen and methane cycling. We propose that aerobic ammonium oxidation is carried out by a diverse community of Thaumarchaeota in the upper zone of the OMZ, whereas a low diversity of Scalindua-like anammox bacteria contribute significantly to nitrogen loss in the core zone. Aerobic nitrite oxidation in the OMZ seems to be performed by Nitrospina spp. and a novel lineage of nitrite oxidizing organisms that is present in roughly equal abundance as Nitrospina. Dissimilatory nitrate reduction to ammonia (DNRA) can be carried out by yet unknown microorganisms harbouring a divergent nrfA gene. The metagenomes do not provide conclusive evidence for active methane cycling, however, a low abundance of novel alkane monooxygenase diversity was detected. Taken together our approach confirmed the genomic potential for an active nitrogen cycle in the Arabian Sea and allowed detection of hitherto overlooked lineages of carbon and nitrogen cycle bacteria. 


\section{Metagenomic analysis of nitrogen and methane cycling in

Claudia Lüke ${ }^{1 *}$, Daan R. Speth ${ }^{1 *}$, Martine A.R. Kox ${ }^{1}$, Laura Villanueva ${ }^{3}$, Mike S.M. Jetten ${ }^{1,2,4}$

${ }^{1}$ Department of Microbiology, IWWR, Radboud University Nijmegen, Nijmegen, the 19 Netherlands

$20{ }^{2}$ Department of Biotechnology, Delft University of Technology, Delft, the Netherlands.

$21{ }^{3}$ Department of Marine Organic Biogeochemistry, Royal Netherlands Institute for Sea Research 22 (NIOZ), 't Horntje (Texel), the Netherlands

$23 \quad{ }^{4}$ Soehngen Institute of Anaerobic Microbiology, Nijmegen, the Netherlands 24 


\section{Abstract}

28 Oxygen minimum zones (OMZ) are areas in the global ocean where oxygen concentrations drop

29 to below one percent. Low oxygen concentrations allow alternative respiration with nitrate and

30 nitrite as electron acceptor to become prevalent in these areas, making them main contributors to

31 oceanic nitrogen loss. The contribution of anammox and denitrification to nitrogen loss seems to

32 vary in different OMZs. In the Arabian Sea, both processes were reported. Here, we performed a

33 metagenomics study of the upper and core zone of the Arabian Sea OMZ, to provide a

34 comprehensive overview of the genetic potential for nitrogen and methane cycling. We propose

35 that aerobic ammonium oxidation is carried out by a diverse community of Thaumarchaeota in

36 the upper zone of the OMZ, whereas a low diversity of Scalindua-like anammox bacteria

37 contribute significantly to nitrogen loss in the core zone. Aerobic nitrite oxidation in the OMZ

38 seems to be performed by Nitrospina spp. and a novel lineage of nitrite oxidizing organisms that

39 is present in roughly equal abundance as Nitrospina. Dissimilatory nitrate reduction to ammonia

40 (DNRA) can be carried out by yet unknown microorganisms harbouring a divergent $n r f A$ gene.

41 The metagenomes do not provide conclusive evidence for active methane cycling, however, a

42 low abundance of novel alkane monooxygenase diversity was detected. Taken together our

43 approach confirmed the genomic potential for an active nitrogen cycle in the Arabian Sea and

44 allowed detection of hitherto overlooked lineages of carbon and nitrogen cycle bacteria. 


\section{Introduction}

46 Oxygen is a key parameter for biogeochemical cycling and has major impact on the marine

47 nitrogen and carbon turnover. The vast majority of the global ocean waters is well oxygenated,

48 allowing aerobic micro- and macro-organisms to thrive. However, in several areas, underlying regions of high productivity, dissolved oxygen concentrations drop to very low levels. These regions are referred to as oxygen minimum zones (OMZ). There is not a general agreement on the definition of an $\mathrm{OMZ}$, however, an oxygen concentration of $\leq 20 \mu \mathrm{M}$ was proposed (Lam \& Kuypers, 2011). Using this threshold, approximately $1 \%$ of the total ocean volume can be defined as an OMZ (Lam \& Kuypers, 2011). In the eastern tropical North Pacific (ETNP), the eastern tropical South Pacific (ETSP) and the Arabian Sea, the three prominent OMZs, oxygen concentration can even drop below levels detectable by sensitive modern techniques (Revsbech et al., 2009; Thamdrup, Dalsgaard \& Revsbech, 2012).

57 Despite comprising only a small fraction of the total ocean volume, OMZs contribute $30-50 \%$ of 58 the nitrogen loss from the ocean (Gruber \& Sarmiento, 1997; Codispoti et al., 2001). This can be 59 attributed to a highly active nitrogen cycle in these systems (Lam \& Kuypers, 2011). After 60 depletion of oxygen, nitrate is the next most energetically favourable terminal electron acceptor 61 and is present in micro-molar concentrations in OMZs (e.g. Pitcher et al., 2011). Nitrate 62 reduction coupled to the oxidation of organic matter releases 16 mole ammonium per mole organic matter oxidized (Redfield et al, 1963). In addition to this, ammonium can be produced by

64 dissimilatory nitrite reduction to ammonium (DNRA). Despite being aerobic processes, 65 ammonium and nitrite oxidation occur in OMZs, partially converting the ammonium back to 66 nitrite and nitrate (Kalvelage et al., 2011, 2015; Füssel et al., 2012). Eventually, nitrogen is lost 
67 from the system due to denitrification (Groffman et al., 2006; Ward et al., 2009) or anaerobic

68 ammonium oxidation (anammox) (Kuypers et al., 2003; Kalvelage et al., 2015).

69 The relative contribution of anammox and denitrification to nitrogen loss from OMZs has been

70 the subject of debate (Lam \& Kuypers, 2011). Before the discovery of anammox, denitrification

71 was thought to be the only contributor (Codispoti \& Richards, 1976; Lipschultz et al., 1990;

72 Devol et al., 2006), but the detected ammonium concentrations were lower than expected based

73 on just denitrification. After the discovery of the anammox process in the Black Sea (Kuypers et

74 al., 2003), anammox bacteria were shown to occur in all the major OMZ using marker genes,

75 lipid analysis, FISH and stable isotope pairing (e.g. Kuypers et al., 2005; Thamdrup et al., 2006;

76 Hamersley et al., 2007). In the ETSP OMZ, anammox was the dominant process involved in

77 nitrogen loss (Lam \& Kuypers, 2011; Stewart, Ulloa \& DeLong, 2012). For the Arabian Sea

$78 \mathrm{OMZ}$, evidence for both denitrification and anammox as the dominant cause of nitrogen loss

79 exists (Ward et al., 2009; Jensen et al., 2011; Pitcher et al., 2011) and the contribution of either

80 process likely varies with season and location.

81 Previous studies on nitrogen cycling the Arabian Sea OMZ focused on one or (a comparison of)

82 a few processes such as ammonia oxidation (Newell et al., 2011; Schouten et al., 2012),

83 denitrification (Jayakumar et al., 2004; Ward et al., 2009), and anammox (Jensen et al., 2011;

84 Pitcher et al., 2011; Villanueva et al., 2014). A recent study used metagenomes obtained from

85 samples across the ETSP, ETNP and the Bermuda Atlantic Time-series Station to access the

86 distribution of iron and copper containing nitrogen cycle enzymes in these systems (Glass et al.,

87 2015), but a comprehensive study of the nitrogen cycling potential in the Arabian Sea OMZ is

88 lacking. 
89 Furthermore, only very little is known on methane turnover in oxygen minimum zones. Low

90 concentrations of methane have been reported at sites of the ETNP and the ETSP suggesting the

91 possibility of methane cycling in these ecosystems (Sansone \& Popp, 2001, Padilla et al., 2016).

92 In addition, $p m o A$ genes (encoding the particulate methane monooxygenase, see Table 1) have

93 been detected in the water column of the ETSP OMZ indicating the presence of aerobic

94 methanotrophs (Tavormina et al., 2013). In the Arabian Sea, high methane concentrations (up to

$95227 \%$ saturation compared to atmospheric levels) have been measured in the surface waters

96 (Owens et al., 1991; Bange et al., 1998; Upstill-Goddard, Barnes \& Owens, 1999) and elevated

97 concentrations (up to approximately $8 \mathrm{nM}$ ) were found at 150-200m depths (Jayakumar et al.,

98 2001). Not much is known about the processes and the organisms involved in production or

99 turnover, but recently Thaumarchaeota cleaving methylphosphonates have been proposed as a

100 potential source of methane in the oceans (Metcalf et al., 2012).

101 Metagenomics is a powerful tool to provide an all-inclusive picture of the functional potential of 102 an ecosystem. As sequencing is becoming easier and less expensive, the bottleneck in 103 metagenomics is shifting from data generation to sequence analysis strategies. Here, we

104 developed a new analysis strategy for mining metagenome data, based on curated databases of 105 marker genes for nitrogen and methane cycle processes (see Table 1 for an overview of the used 106 marker genes). We applied this strategy to metagenome data retrieved from two depths along the 107 oxygen gradient of the Arabian Sea OMZ.

108

109 Materials and methods

110 Sampling and sample preparation 
111 Samples used in this manuscript were collected in the Arabian Sea OMZ during the PASOM

112 cruise funded by the Netherlands Organization for Scientific Research (NWO) under number

113 817.01.015. The sampling site and sampling procedure are described in detail in a previous study

114 (Pitcher et al., 2011). Briefly, the site is located within the Arabian Sea (lat. 21 ${ }^{\circ} 55.6^{\prime}$, long.

$\left.11563^{\circ} 10.6^{\prime}\right)$ and influenced by Persian Gulf Water and Red Sea Water. It is just outside the region

116 characterized by a quasi-permanent secondary nitrite maximum (Revsbech et al., 2009). Twelve

117 samples were taken along a depth profile (stations PA1-PA12) in the water column ranging from

118 the ocean surface $(0 \mathrm{~m})$ down to $2000 \mathrm{~m}$ below the surface (total water depth at this site is

$1193010 \mathrm{~m}$ ). Dissolved oxygen concentrations decreased from fully saturated concentrations at the

120 surface to $3.2 \mu \mathrm{M}$ at the core of the OMZ. The latter value reflects the detection limit of the CTD

121 oxygen sensor, the real values are probably substantially lower as suggested by STOX

122 (Switchable Trace amount OXygen; Revsbech et al., 2009) sensor measurements in the Arabian

123 Sea OMZ, where reported values were $\leq 0.09 \mu \mathrm{M}$ which was the detection limit of the sensor in

124 that sampling campaign (Jensen et al., 2011).

125 In our sampling dataset, the depth of $170 \mathrm{~m}$ below ocean surface was defined as OMZ transition

126 zone whereas the depth of $600 \mathrm{~m}$ belongs to the OMZ core zone at this sampling site (Pitcher et

127 al., 2011). Oxygen concentrations increased again at $1050 \mathrm{~m}$ (Pitcher et al, 2011). At $170 \mathrm{~m}$

128 depth, the ammonium concentration showed a peak $(0.14 \mu \mathrm{M})$, nitrite concentrations had peaks

129 at $170 \mathrm{~m}$ and $600 \mathrm{~m}$ below surface (Pitcher et al., 2011). Furthermore, biomarker analysis based

130 on the distribution of lipids and copy numbers of the 16S rRNA / amo $A$ (encoding the ammonia

131 monooxygenase) / $h d h$ (encoding the hydrazine dehydrogenase) genes and/or transcripts

132 indicated highest numbers of Thaumarchaeota at $170 \mathrm{~m}$ and highest numbers of anammox at 600

133 m depth (Pitcher et al., 2011). Thus, in this study we focused on two different depths in the water 
134 column: $170 \mathrm{~m}$ below ocean surface (station PA2) and $600 \mathrm{~m}$ below ocean surface (station PA5).

135 Main physiochemical parameters were taken from Pitcher et al. (2011) and are reported in Table

136 S1. From these depths, large-volumes of seawater (200-1700 L) were filtered through 142-mm

137 diameter $0.2 \mu \mathrm{m}$ polycarbonate filters (Millipore, Billerica, MA). Filters were cut into fragments

138 and DNA extraction was performed as described by Pitcher and co-workers (Pitcher et al., 2011).

139 After extraction, DNA was precipitated using ice-cold ethanol, dried, and re-dissolved in $100 \mu \mathrm{l}$

140 of $10 \mathrm{mM}$ Tris-HCl, $\mathrm{pH}$ 8. Total nucleic acid concentrations were quantified

141 spectrophotometrically (Nanodrop, Thermo Scientific, Wilmington, DE, USA) and checked by

142 agarose gel electrophoresis for quality. Extracts were kept frozen at $-80^{\circ} \mathrm{C}$.

144 Ion Torrent library preparation and sequencing

145 All kits used in this section were obtained from Life technologies (Life technologies, Carlsbad,

146 CA, USA). For both samples an identical library preparation was performed. Genomic DNA was

147 sheared for 7 minutes using the Ion Xpress ${ }^{\mathrm{TM}}$ Plus Fragment Library Kit following the

148 manufacturer's instructions. Further library preparation was performed using the Ion Plus

149 Fragment Library Kit following manufacturer's instructions. Size selection of the library was

150 performed using an E-gel ${ }^{\circledR} 2 \%$ agarose gel, resulting in a median fragment size of approximately

151330 bp. Emulsion PCR was performed using the OneTouch $200 \mathrm{bp}$ kit and sequencing was

152 performed on an Ion Torrent PGM using the Ion PGM 200 bp sequencing kit and an Ion 318

153 chip, resulting in 4.9 million reads for station PA2 and 2.6 million reads for station PA5. The raw

154 reads were submitted to the NCBI Sequence Read Archive under the accession number 155 SRA304624. 
157 Bioinformatics

158 Quality assessment and assembly feasibility

159 Raw sequence reads were imported into the CLC Genomics Workbench (v7.0.3, CLCbio Arhus,

160 Denmark) and end-trimmed on quality using the CLC genomics default settings (quality limit

1610.05 and two ambiguous nucleotides allowed) and length ( $\geq 100 \mathrm{bp}$ ) resulting in 3.3 million

162 reads of station PA2 and 1.6 million reads from station PA5, which were used for subsequent 163 analyses.

164 To assess the feasibility of assembly for the analysis of the read data, the datasets were

165 assembled de novo using the CLC genomics workbench with word size 35 and bubble size 5000.

166 Using the data from both sampling sites combined, this resulted in 5105 contigs longer than

$1671000 \mathrm{bp}$, incorporating only $7.6 \%$ of the reads. Based on the results of the metagenome

168 assembly, we decided to employ a read based analysis strategy.

\section{$16916 S$ rRNA gene analysis}

170 To extract reads matching the ribosomal small subunit for taxonomic classification, the SILVA

171 SSU RefNR99 dataset (version 115, Quast et al., 2013) was used as reference. First, the 172 metagenome reads were mapped against the SILVA dataset using the CLC Genomics

173 Workbench (mismatch penalty 2, In/Del penalty 3, 50\% identity over $70 \%$ of the sequence).

174 Mapped reads were extracted and used for BLAST searches against the identical SILVA dataset

175 (E-value cut-off $10^{-6}$ ). Positive hits were aligned using the SINA aligner (Pruesse, Peplies \& 176 Glockner, 2012) and imported into the SILVA refNR99 version 115 ARB database (Quast et al.,

177 2013). Sequences were added to the existing Neighbor Joining 16S rRNA tree (including nearly

$178500,00016 \mathrm{~S}$ rRNA sequences) using maximum parsimony criteria without optimization of the

179 tree topology (ARB parsimony Quick add marked). All phylogenetic clusters containing reads 
180 from our metagenomes were visually inspected and the number of reads in the respective cluster

181 was recorded. For reads that did not cluster unambiguously to a specific group, the phylogeny of

182 the higher taxonomic level was recorded.

183

184 Functional gene analysis

185 Construction of reference datasets

186 To screen the metagenomes for potential function, reference datasets of marker genes (amino

187 acid sequences) were manually curated. Marker genes for nitrogen cycle processes (nitrogen

188 fixation, nitrification, denitrification, dissimilatory nitrite reduction to ammonia (DNRA) and

189 anammox) and marker genes for methane cycle processes (methanogenesis, methane oxidation,

190 methylphosphonate turnover) were selected. Table 1 gives an overview of genes and gene

191 products used in this study. Reference databases were curated for all genes individually. Where

192 available, existing databases were used as a reference, as for the nifH gene (Gaby \& Buckley,

193 2014), the bacterial amoA/pmoA gene (Dumont et al, 2014), the archaeal amoA gene (Pester et

194 al., 2012) and the mcrA gene (Angel et al, 2011). From these ARB databases, a subset (490 nifH

195 sequences, 167 bacterial pmoA/amo A sequences also including novel clades from a manuscript in

196 revision (all sequences are provided in the supplement), 134 archaeal amo $A$ sequences, 124

197 methanogen $\operatorname{mcr} A$ sequences) covering the main described clusters was selected from the

198 phylogentic trees in ARB and extracted for the analysis in this study. For the mcr $A$ gene, 78

199 sequences from described methanotrophic ANME clusters (Knittel \& Boetius, 2009) were added

200 to the selection. In addition, $m c r A$ sequences from Bathyarchaeota (Evans et al., 2015) were

201 downloaded from NCBI. For the remaining genes (hao/hdh, narG/nxrA, nirS, nirK, nosZ, nrfA,

$202 h z s A, m m o X, m p n S$, phnGHI), sequences were collected from public databases (proteins that 
203 matched to the respective Interpro family and keyword/accession number search in $\mathrm{NCBI})$. The

204 amino acid sequences were downloaded and aligned using Clustal Omega (Sievers et al., 2011).

205 Alignments were manually inspected and for sequences with large gaps or insertions, literature

206 was queried to verify the function of the respective enzyme. In cases where the function of a

207 divergent sequence has not been described or is different than the target database, the sequence

208 was discarded. The remaining aligned sequences were imported into ARB. Sequences with

209 ambiguous characters or obvious shifts in reading frame were removed. The remaining

210 sequences were used for phylogenetic tree construction. Phylogenies were compared to literature

211 to verify that the known and described phylogenetic groups are covered and that the dataset is

212 representative. For the norB/nor $Z$ database, all sequences in the cytochrome oxidase PFAM

213 family (PF00115) were downloaded, replicates were removed using UClust (80\% identity)

214 (Edgar, 2010) and the clustered sequences were screened against characterized cNOR

215 (cytochrome c dependent nitric oxide reductase) and qNOR (quinol dependent nitric oxide

216 reductase) sequences using a BLAST score ratio (BSR) (Rasko, Myers \& Ravel, 2005).

217 Sequences with a BSR over 0.4 were included in the database. Representatives of phylogenetic

218 clusters (distance level of 0.1) were exported in fasta format and imported into ARB where

219 sequences with ambiguous characters or obvious shifts in reading frame were removed. The

220 remaining sequences were used for phylogenetic tree construction and exported as reference set

221 for subsequent BLAST analysis. All reference sets are provided as supplementary material.

223 BLAST analysis using the reference datasets

224 The reads of the metagenomes described above were used in BLASTx searches against the

225 reference sets (E-value cutoff $10^{-6}$ ). The E-value was established after first test analyses with 
226 different E-values $\left(10^{-4}\right.$ to $\left.10^{-6}\right)$. Positive hits were extracted using a custom perl script available 227 at www.github.com/dspeth. In a second step, positive reads were used in BLASTx searches 228 against the NCBI NR database. For reference datasets resulting in low number of target 229 sequences (approximately $\mathrm{n}<100$ ), false positive reads were removed by manual inspection of 230 the BLAST results. For large number of target reads (approx. $n>100$ ), a modified BLAST score 231 ratio (BSR) approach was used to remove false positive hits while keeping divergent sequences. 232 In this approach, rather than calculating the ratio between the score of a hit against our database 233 and the maximum score (of a self-hit) for every read (Rasko, Myers \& Ravel, 2005), we 234 calculated the ratio between a hit against our database and a hit against the NCBI-NR database 235 (NCBI non-redundant protein sequence database, see Figure S2 for the procedure overview). 236 This guaranteed that sequences with low similarity to both NR and our database were kept as 237 true positives, whereas reads with a much better hit to the NR than to our database were 238 discarded as false positives. We determined a separate threshold value for a positive hit for each 239 specific gene database (Table 1). This threshold was selected based on a first manual inspection 240 of reads with different bit-score ratios (Figures S3-S7). To distinguish between the closely 241 related hao (encoding the hydroxylamine oxidoreductase) and $h d h$ (encoding the hydrazine 242 dehydrogenase) sequences and the $\operatorname{nar} G$ (encoding the nitrate reductase) and $n x r A$ (encoding the 243 nitrite oxidoreductase) sequences respectively, a second step was applied. Positive hao reads 244 obtained after the BSR analysis were mapped in CLC genomics (mismatch penalty 2, In/Del 245 penalty 3 , minimum $50 \%$ identity over $50 \%$ of the read) against both copies of the Scalindua 246 brodae $h d h$ (accession numbers: KHE92657.1, KHE91265.1). Mapped reads were extracted and 247 classified as $h d h$, non-mapped reads were classified as hao. To distinguish between $\operatorname{nar} G$ and $248 n x r A$, positive nar $G$ reads obtained after the first BSR analysis were used in a second round of 
249 BLASTx against two nxrA gene subsets, one containing the Nitrobacter/Nitrococcus/Nitrolancea

$250 n x r A$ sequences and the other containing the Nitrospira/Nitrospina/anammox $n x r A$ sequences. A

251 BSR cut-off of 0.85 was used to separate nxrA from narG.

252 For all genes, after removal of false positive targets using the BSR analysis, reads were assigned

253 to taxonomy using MEGAN (Huson et al., 2007, Huson et al., 2011) and the taxonomy of

254 maximum 5 hits with over $90 \%$ score from the top hit.

255

256 Normalization of metagenomic read counts

257 After phylogenetic assignment, the positive read counts were normalized according to gene

258 length and metagenome size according to the following procedure: (Number of positive reads) /

259 ((length of gene in $\mathrm{bp}) *$ (number of total reads in the metagenome)). The rpoB gene (encoding

260 the RNA polymerase) was used as a single copy gene reference. To estimate the abundance of

261 microorganisms encoding nitrogen or methane cycling marker genes in their genomes, the

262 normalized read counts were discussed as fraction of the normalized total read counts of the $263 r$ rpoB gene.

264

265 Assembly of selected reads

266 For selected genes $(h d h, h z s A$, nirS, $n r f A, n x r A)$, the reads were extracted and imported in the

267 CLC genomics workbench to reconstruct (near) full-length genes. In all cases, reconstruction

268 through direct assembly (word size 35, bubble size 5000) was attempted. This was successful for

$269 h z s A$, nirS and $n r f A$, where diversity was limited. For the more diverse data ( $n x r A$ and $h d h$ )

270 iterative mapping (Dutilh, Huynen \& Strous, 2009) was used. Hdh could be reconstructed by

271 mapping against both copies of Scalindua brodae hdh (KHE92657.1 \& KHE91265.1; mismatch 
272 penalty 2 , In/Del penalty 3 , minimum $50 \%$ identity over $50 \%$ of the read). The $n x r A$ sequences 273 of Nitrospina $s p$. and Scalindua sp. were reconstructed by iterative mapping on the sequences of 274 Nitrospina gracilis and Scalindua brodae (WP_042250442.1 \& KHE93157.1; mismatch penalty 2752 , In/Del penalty 3, minimum $80 \%$ identity over $50 \%$ of the read). Novel nxrA sequences were 276 retrieved using iterative mapping of the reads that could not be assigned to either Nitrospina or 277 Scalindua on the nxrA sequence of Kuenenia stuttgartiensis (CAJ72445.1; mismatch penalty 1, $278 \mathrm{In} /$ Del penalty 3 , minimum $30 \%$ identity over $50 \%$ of the read). 


\section{Results and discussion}

280 Metagenomics can be used as powerful tool to gain insights into the functional potential of an

281 ecosystem. As the sequencing procedure itself is becoming easier and less expensive resulting in

282 generation of large amounts of data, sequence analysis strategies are becoming a bottleneck in

283 time and resources. Depending on the diversity and complexity of the dataset, different analysis

284 approaches are needed. In this study, we provide a strategy for the systematic screening of

285 metagenomes for nitrogen and methane cycling potential using curated functional gene reference

286 databases. We applied our strategy to a dataset from the Arabian Sea oxygen minimum zone

287 (OMZ) analysing the genetic potential for nitrogen and methane turnover in the upper limit

288 (station PA2) characterized by low oxygen (approximately $5 \mu \mathrm{M}$, Table S1) and the core zone

289 (station PA5) in which the oxygen concentration drops below the detection limit $(3.4 \mu \mathrm{M})($ Table 290 S1).

291 Taxonomy based on 16S rRNA gene analysis

292 To get insight into the overall microbial community in the Arabian Sea OMZ, we analysed 293 16S rRNA gene reads retrieved from the metagenomes at station PA2 and PA5 (Figure 1). At the 294 upper limit of the OMZ (station PA2, Table S1), the SAR11 clade (Alphaproteobacteria) formed 295 one of the most abundant microbial groups (14\%). This clade represents in general one of the 296 most abundant microorganisms in seawater, contributing up to $30 \%$ of all bacterioplankton 297 (Morris et al., 2005). Sub-clusters within the SAR11 clade have been linked to ecotypes 298 occupying different niches in the ocean water column (Field et al., 1997; Vergin et al., 2013). In 299 the PA2 dataset, most sequence reads clustered within SAR11 subgroup 1, closely related to 300 cultivated strains of 'Candidatus Pelagibacter ubique'. ' $C a$. P. ubique' has a small, streamlined 301 genome adapted to rapid heterotrophic growth (Rappe et al., 2002; Giovannoni et al., 2005) and 
302 is unlikely to directly contribute to nitrogen cycling in the Arabian Sea OMZ. The remainder of

303 the SAR11 reads were distributed across the entire SAR11 clade. Ammonium oxidizing Archaea

304 (AOA) of the Marine Group I (MG-I) Thaumarchaeota were as abundant as SAR11 at station

305 PA2 (14\%), confirming previous PCR- and lipid-based analyses showing that Thaumarchaeota

306 were abundant at this location (Pitcher et al., 2011). Both SAR11 and MG-I were less abundant

307 in the OMZ core, but still have a substantial presence of $8.1 \%$ and $3.3 \%$ respectively (Figure 1 ).

308 Reads affiliated with the bacterial SAR86 clade (Gammaproteobacteria) and archaeal Marine

309 Group II (MG-II) made up 8\% and 7\% of the $16 \mathrm{~S}$ rRNA gene reads at station PA2, but were only

310 marginally present in the OMZ core (1.5\% and $0.4 \%$ of the reads, respectively). This is

311 consistent with an aerobic heterotrophic lifestyle predicted from previously obtained genomes of

312 organisms of both lineages (Dupont et al., 2012; Iverson et al., 2012). So far, no metabolic

313 adaptations of these organisms to an anaerobic lifestyle have been characterized. Nevertheless,

314 the persistence, albeit in low abundance, of aerobic organisms in the anoxic OMZ core might be

315 partially explained by the attachment to slowly sinking organic particles, also referred to as

316 marine snow (Wright, Konwar \& Hallam, 2012). Formed in the metabolically active photic zone,

317 these particles continuously sink through the water column to the floor of the ocean and thereby

318 also passing the anoxic core of the OMZ. Association to particles has been previously proposed

319 for SAR11 (Zeigler Allen et al., 2012) and demonstrated for the MG-II Archaea (Orsi et al., 320 2015).

321 The deep-branching bacterial phylum Marinimicrobia (formerly SAR406) (Fuhrman, Mccallum

322 \& Davis, 1993; Gordon \& Giovannoni, 1996; Rinke et al., 2013) comprised 9\% of all 16S rRNA

323 affiliated sequence reads at station PA2 and 20\% at PA5. A recent transcriptome study indicates

324 the involvement of these bacteria in extracellular proteolysis and fermentative amino acid 
325 degradation in a methanogenic environment (Nobu et al., 2015). These findings of an anaerobic

326 lifestyle agree well with their high abundance in a low oxygen environment (upper OMZ) and

327 their dominance in the OMZ core. The detected Rhodospirillales (Alphaproteobacteria) might

328 also contribute to fermentation of organic matter, as this order comprises known acetic acid

329 bacteria. Rhodospirillales were barely detectable at the OMZ upper limit, but comprise $4.1 \%$ of

330 the community at the OMZ core. Other abundant lineages include the Deltaproteobacteria

331 SAR324. These bacteria are frequently found in the ocean and seem to be correlated with low

332 oxygen concentrations (Wright, Konwar \& Hallam, 2012; Sheik, Jain \& Dick, 2014). SAR324

333 representatives have been shown to be able to fix $\mathrm{CO}_{2}$ (Swan et al., 2011) and are predicted to be

334 capable of autotrophic denitrification with various electron donors (Sheik, Jain \& Dick, 2014).

335 Likewise, Gammaproteobacteria of the SUP05 lineage have been implied in autotrophic

336 denitrification with sulphur as electron donor (Lavik et al., 2009; Walsh et al., 2009; Russ et al.,

337 2014). They furthermore have been associated with cryptic sulfur cycling in the ETSP OMZ

338 (Canfield et al., 2010). Members of both SAR324 and SUP05 have a similar presence at both

339 stations (5\% in PA2 and 3.1\% in PA5 for the SAR324 lineage, $2.9 \%$ and $2.7 \%$ for the SUP05

340 lineage), with SAR324 slightly decreasing in the OMZ core (Figure 1).

341 Anammox 16S rRNA genes are barely detected at the upper limit of the OMZ, consistent with

342 previous analyses (Pitcher et al., 2011; Villanueva et al., 2014), but comprise almost 5\% of the

343 community at the $\mathrm{OMZ}$ core. Interestingly, a recent study showed that autotrophic denitrifiers

344 oxidizing hydrogen sulphide could form a stable community with anammox bacteria in a reactor

345 system (Russ et al., 2014). Whether this is also the case at the OMZ core remains to be

346 investigated. Although some of the lineages discussed above are abundant, assembly of the 
347 complete metagenome reads did not yield any contigs with high sequencing depth, indicating the

348 diversity within each lineage is substantial.

349 To assess the diversity and phylogeny of the detected AOA and anammox bacteria in more

350 detail, reads matching the $16 \mathrm{~S}$ rRNA gene of either group were extracted and assembled into

351 contig sequences for phylogenetic tree construction. Reads affiliated with MG-I AOA from the

352 OMZ upper limit (PA2) could be assembled into two representative contigs: Contig-1 comprises

$35341 \%$ of all extracted MG-I reads and contig- 2 was built from $15 \%$ of the reads. Thus, the two

354 contigs represent the majority of the thaumarchaeotal community. Nevertheless, these sequences

355 do not represent a single genotype but represent a hybrid of $16 \mathrm{~S}$ rRNA reads from multiple

356 closely related organisms (Figure S1). Contig-1 shows 98\% identity to the very recently

357 described 'Candidatus Nitrosopelagicus brevis' (Figure 2) (Santoro et al., 2015), contig-2 has

358 only moderate identities to isolated or enriched ammonia oxidizers (93\% identity to

359 Nitrosoarchaeum limnia SFB1) (Figure 2).

360 Reads from station PA5 clustering with the Brocadiaceae, the family comprising all known

361 anammox bacteria, were extracted and could be assembled into one representative sequence.

362 Here, diversity was considerably less than for the Thaumarchaeota and the contig represents a

363 single genotype that is $96 \%$ identical to Scalindua brodae, the closest sequenced relative (Speth

364 et al., 2015), and 99\% identical to 'Candidatus Scalindua arabica' clones previously obtained

365 from the Arabian sea OMZ (Figure 3) (Woebken et al., 2008). Interestingly, sequences obtained

366 by Ward and co-workers from the Arabian Sea OMZ share only 97\% sequence identity to the

367 extracted contig (Ward et al., 2009) indicating a spatial or temporal niche differentiation of

368 different Scalindua-like ecotypes in this system. 
372 Genetic potential for nitrogen and methane cycling

373 To assess the nitrogen and methane cycling potential in the metagenome of both the upper limit

374 and the core of the OMZ, we performed BLASTx searches of the metagenomic reads against

375 curated databases of key genes (Table 1) involved in nitrogen and methane cycle processes. To

376 remove false positive hits while keeping divergent sequences, we used a modified BLAST score

377 ratio (BSR) approach (see methods section).

378

379 Nitrogen cycling potential

380 Nitrification

381 Marker genes indicative for the first step in nitrification, the conversion from ammonia to nitrite,

382 are the amoA (encoding a subunit of the membrane bound ammonium monooxygenase) and the

383 hao gene (encoding the hydroxylamine oxidoreductase). We found 228 reads matching amoA in

384 the PA2 dataset, 227 of which could be assigned to ammonia oxidizing Archaea (AOA),

385 indicating that they contribute approximately $25 \%$ to the total microbial community in this

386 sample (Figure 4). This estimate exceeds the estimated abundance based on 16S rRNA genes

387 (Figure 1). Our analysis strategy includes the correction for sequencing depth and gene length,

388 however, no correction for gene copy numbers was applied. This information can only be

389 deduced from genomes and is not known for the vast majority of microorganisms. In the

390 presence of genomes harbouring multiple rRNA operons, the total number of detected organisms

391 is artificially inflated, leading to an underestimation of organisms with a single rRNA operon

392 which would explain the lower 16S rRNA estimates in this dataset. An alternative, albeit less

393 likely, explanation for higher amo $A$ estimates can be the presence of multiple copies of the amo $A$ 
394 gene in the detected AOA genomes, but this has not been observed in any previously sequenced 395 AOA species.

396 The amoA reads could be assembled into 5 major contigs (4 contigs from site PA2 and 1 contig 397 from PA5) that were compared to $16 \mathrm{~S}$ rRNA phylogeny (Figure 1). As for the 16S rRNA contig, 398 amoA sequences could not be affiliated with a single MG-I species, but showed a diversity of at 399 least 2 major genotypes. Unlike the 16S rRNA gene analysis, none of the contigs clustered with 400 Nitrosopelagicus-like amoA sequences. Instead two out of the four obtained contigs from PA2 401 did not cluster with, but between the Nitrosopelagicus cluster and Nitrosoarchaeum limnia 402 SFB1. The two other contigs clustered within an environmental group only distantly related to 403 described MG-I AOA. This environmental cluster also contained the only contig that could be 404 assembled from the OMZ core. A niche differentiation between shallow and deep-water clades 405 of MG-I Thaumarchaeota has also been described before in the Arabian Sea OMZ (Villanueva, 406 Schouten \& Sinninghe Damsté, 2014), but also in other marine environments (Beman, Popp \& 407 Francis, 2008; Santoro, Casciotti \& Francis, 2010). Besides archaeal amoA, only a single read 408 with low identity ( $<50 \%$ on the amino acid level) to known bacterial amoA reads was detected, 409 indicating ammonium oxidizing bacteria (AOB) likely play only a small role in the Arabian sea 410 OMZ although they were detected in other OMZs (Molina et al., 2007; Lam et al., 2009).

411 Consistent with the absence of AOB amoA, only five reads matching hao were detected in the 412 upper limit of the OMZ. In the core, 475 reads matched the hao database, but even after removal 413 of the bonafide anammox hydrazine dehydrogenase hits (Figure 3), over $90 \%$ of the hao matches

414 were affiliated with Scalindua, which is known to encode up to ten paralogs of this protein (van 415 de Vossenberg et al., 2013; Speth et al., 2015). 
416 The second step of complete nitrification, nitrite oxidation, is challenging to study using a

417 marker gene approach as nitrite oxidoreductase $(\operatorname{Nxr} A)$ and nitrate reductase $(\operatorname{Nar} G)$ are

418 homologous enzymes. A further complicating factor is the polyphyletic nature of the $n x r A$ gene

419 (Lücker et al., 2010). To account for this, we first extracted all the reads matching a combined

$420 n a r G / n x r A$ reference set, and then used a second round of BLASTx and BLAST score ratio

421 separation (threshold $0.85-0.95$ ) to distinguish between $\operatorname{nar} G$ and $n x r A$. No reads could be

422 confidently assigned to nxrA of the Nitrobacter / Nitrococcus / Nitrolancetus group in either

423 station. Conversely, $33 \%$ and $23 \%$ of the reads matching $n a r G / n x r A$ were assigned to $n x r A$ of

424 the Nitrospira / Nitrospina / anammox group in PA2 and PA5, respectively. Further separation

425 between $n x r A$ matches, to distinguish the nitrifier nxrA from anammox, was achieved using

426 iterative mapping. Classification using MEGAN indicated that anammox made up 44\% of the

427 reads matching $n x r A$ at station PA2. As all other analyses indicated anammox bacteria were

428 virtually absent from this station (Figure 1 and Table S2), we explored these reads in detail using

429 iterative mapping and manual curation of the sequences. This led to the identification of a novel

430 lineage of nxrA clustering between anammox and Nitrospina sequences (Figure 5), which was

431 slightly more abundant than the retrieved Nitrospina sp. at both station PA2 (approx. $2 \%$ and 1.5

$432 \%$ of the population respectively) and PA5 (approx. $3 \%$ and $2 \%$ of the population respectively).

433 Interestingly, distinct lineages of both the putative novel nitrite oxidizer and Nitrospina seemed

434 to occupy either station (Figure 5). The abundance of anammox $n x r A$ in the OMZ core sample

435 correlates well with the abundance as assessed using the 16S rRNA gene (Table 1) and other 436 anammox markers (Table S3, discussed below). 
437 No other nitrite oxidizing organisms were detected. The detection of a significant abundance of

438 nitrite oxidizers in OMZ ecosystems is consistent with a previous study showing that nitrite 439 oxidation was an active process in the Namibian OMZ (Füssel et al., 2012).

442 Genetic potential for processes contributing to nitrogen loss

443 Nitrite and nitrate resulting from nitrification can be readily used in denitrification, anammox 444 and DNRA. To date, it is still unclear which process is dominating or if a combination of various 445 processes occurs. Most of the recent studies indicated anammox instead of denitrification as 446 prevalent pathway in OMZs (Kuypers et al., 2005; Thamdrup et al., 2006; Hamersley et al., 447 2007; Lam et al., 2009). However, two reports described high and active denitrification rates in 448 the Arabian Sea OMZ (Ward et al., 2009; Bulow et al., 2010). In yet another study, Jensen and 449 co-workers found that anammox coupled to DNRA was the prevalent process in this system 450 (Jensen et al., 2011) and further studies confirmed a high abundance of anammox bacteria at the 451 core of the Arabian Sea OMZ (Pitcher et al., 2011; Villanueva et al., 2014).

452 Here, we found that the nitrate reductase is by far the most dominant nitrogen cycle enzyme 453 encoded in the Arabian Sea OMZ core (78\% of normalized rpoB gene abundance, Figure 4). 454 This is consistent with observations in the Peruvian oxygen minimum zone (Lam et al., 2009; 455 Glass et al., 2015) and in the Eastern Tropical South Pacific OMZ (Stewart, Ulloa \& DeLong, 456 2012). The reduction of nitrate to nitrite is a crucial step as the nitrite forms the starting point for 457 many subsequent processes: nitrite reduction in denitrification, in DNRA and in anammox. 458 Additionally, nitrite can also be re-oxidized to nitrate. The genetic potential for all these 459 processes is substantially encoded in the OMZ core. Consistent with Jensen and co-workers 
460 (Jensen et al., 2011), we find the potential for DNRA ( $n r f A$ encoding the penta-heme nitrite

461 reductase as marker gene), approximately in equal abundance to anammox. Upon close

462 inspection $60 \%$ of the reads matching $n r f A$ originate from two closely related strains of an

463 unknown organism. The 812 bp hybrid sequence obtained after assembly has $73 \%$ identity (AA

464 level) to only two sequences in the database: Coraliomargerita akajimensis (Verrucomicrobia)

465 and Pelobacter carbinolicus (Deltaproteobacteria). Although the phylogeny of the organisms

466 most likely responsible for DNRA in the Arabian Sea OMZ remains unclear, retrieval of the

467 divergent $n r f A$ emphasizes the potential of our approach for novel microbiological gene

468 discovery.

469 Only few sequences indicative for the process of denitrification were detected. Although many 470 reads matched nitrite reductase encoded by either nirS or nirK (Table S3), 50\% of all nirS reads

471 could be classified as Scalindua-related. The nirS contig obtained after assembly of the reads

472 matching Scalindua showed 77\% nucleotide sequence identity to Scalindua brodae and 99\%

473 identity to unpublished sequences from the Gulf of California and Eastern Tropical North Pacific

474 OMZs (Genbank accession: KC596869). It corroborates the 16S rRNA gene analysis indicating

475 the presence of one dominant uncultivated anammox ecotype. Of all detected nirK reads, $70 \%$

476 originated from AOA. These Thaumarchaeota are known to harbour multiple copies of NirK-

477 like copper oxidases encoding genes (Stahl \& de la Torre, 2012) explaining their high abundance

478 in the datasets (Figure 4). It has been previously suggested that nitrifier denitrification accounts

479 for the majority of nitrous oxide observed in the ocean (Babbin et al., 2015, Kozlowski et al., 480 2016). Besides playing a role in nitrifier denitrification, these enzymes are also hypothesized to 481 be the missing hydroxylamine oxidoreductase equivalent in AOA catalysing the oxidation of 482 hydroxylamine to nitrite (Stahl \& de la Torre, 2012). 
483 Similar to the nirS-type nitrite reductase genes, we found that $40 \%$ of all reads matching the

484 norB / norZ reference set (encoding the nitric oxide reductase) at both stations combined were 485 affiliated with Scalindua (Table S3). Potential for the final step of denitrification via nitrous 486 oxide reduction (encoded by the nos genes) was limited with 92 reads at station PA2 and only 27 487 reads at station PA5 (Figure 4, Table S3). We could not find genomic indication for nitrogen 488 loss via the nitric oxide dismutase of NC10 phylum bacteria as recently described for the Eastern 489 Pacific OMZ (Padilla et al., 2016).

490 The abundance of anammox marker genes $h z s A$ (encoding the hydrazine synthase) and $h d h$

491 (encoding the hydrazine dehydrogenase) coincides well with the abundance estimates based on 492 16S rRNA, nxrA, and nirS genes consistently indicating that anammox bacteria of the Scalindua 493 genus are present at approximately 5\% abundance.

494 The nifH gene, encoding a subunit of the nitrogenase, was used as marker in screening for 495 nitrogen fixation potential in the Arabian Sea datasets. Ocean circulation models have predicted 496 highest nitrogen fixation rates close to zones of nitrogen loss (Deutsch et al., 2007) and were 497 supported by recent studies reporting the presence and transcription of nifH genes in sub-oxic 498 waters of the Arabian Sea (Jayakumar et al., 2012; Bird \& Wyman, 2013). However, we detected 499 no nifH hits in the PA2 metagenome and only 3 reads matched nifH in the PA5 dataset (Figure 500 3). The nifH genes in the above mentioned studies were obtained using PCR amplification with 501 specific primer sets able to detect a much lower abundance of diazotrophs in the environment.

502 Our results indicate a low abundance of diazotrophs that nevertheless would easily be detected 503 by PCR amplification. We can estimate the abundance of diazotrophs from our dataset, assuming 504 an average microbial genome size of $3 \mathrm{Mbp}$ and the nifH gene length of $900 \mathrm{bp}$. If present in all 505 genomes, 3 reads per 10.000 should contain part of a nifH. However, only 3 reads were detected 
506 in the PA5 metagenome (1,6 million reads), which is 160 times lower and thus results in a

507 diazotroph abundance estimate of $0.6 \%$ based on the dataset. PCR primers should be able to

508 amplify genes present in organisms with this abundance. Alternatively, the diazotrophic

509 community in our dataset was, for unknown reasons, lower than in other studies from similar

510 ecosystems.

511

512 Methane cycling potential

513 To examine the methane cycling potential in the Arabian Sea, we selected marker genes

514 targeting methane production and methane oxidation (Table 1). The $m c r A$ gene (encoding the

515 methyl-Coenzyme $\mathrm{M}$ reductase) was used as functional marker for methane production and

516 anaerobic methane oxidation. We could not detect any $m c r A$-like sequences of canonical

517 methanogens or sequences of the very recently described $\operatorname{mcr} A$ homologues from

518 Bathyarchaeota (Evans et al., 2015). Also no sequences of anaerobic methane oxidizing archaea

519 (ANME clades) were found. This is consistent with the absence of methanogen 16S rRNA genes

520 and very low abundance (3 reads) of Bathyarchaeota $16 \mathrm{~S}$ rRNA gene sequences. Thus,

521 methanogenesis does not seem to play a major role in the Arabian Sea OMZ water column.

522 Nevertheless, in marine ecosystems, a second pathway for methane production apart from

523 methanogenesis was proposed (Karl et al., 2008). This aerobic pathway includes the cleavage of

524 methylphosphonate (Mpn). Mpn was shown to be synthesized by the AOA Nitrosopumilus

525 maritimus using the Mpn synthase as key enzyme and a homologue of this enzyme was also

526 found to be encoded in SAR11 genomes (Metcalf et al., 2012). The cleavage of Mpn that results

527 in the release of methane, is catalysed by the C-P lyase multi-enzyme complex (Daughton, Cook

528 \& Alexander, 1979). In Escherichia coli, the C-P cleavage is encoded in a 14 gene operon 
529 (Metcalf \& Wanner, 1993). The composition of the gene cluster is variable among bacteria,

530 however, the phnGHIJKM genes seem to be conserved and essential for activity (Huang, Su \&

$531 \mathrm{Xu}, 2005)$. We selected the mpnS gene (encoding the Mpn synthase) and the phnGHI genes

532 (encoding components of the C-P lyase pathway) as functional marker genes for aerobic methane

533 production in our datasets. In the PA2 dataset, 45 reads matching the $m p n S$ gene were retrieved,

534 most of which could be affiliated with the MG-I Thaumarchaeota (Figure 6, Table S4).

535 Comparing the $m p n S$ read numbers with corresponding $16 \mathrm{~S}$ rRNA gene and amo $A$ read numbers

536 from Thaumarchaeota results in a far lower abundance of $m p n S$ reads in the dataset. However,

537 this is in good agreement with the observation that not all MG-I Thaumarchaeota encode mpnS

538 in their genome. The dominant MG-I ammonia oxidizer in the Arabian Sea datasets is closely

539 related to Nitrosopelagicus brevis (Figure 2), which does not possess the mpnS gene (Santoro et

540 al., 2015). In the metagenome from the OMZ core zone, $7 \mathrm{mpnS}$ reads (3 reads matching to MG-

541 I) were detected.

542 The C-P lyase gene cluster has been found in many genomes of marine bacteria and could also

543 be associated to growth with Mpn as sole phosphorous source (Dyhrman et al., 2006; Martinez,

544 Tyson \& DeLong, 2010; White et al., 2010). In the Arabian Sea datasets, no reads matching the

545 phnGHI genes were detected in PA2 and only 3 phnI sequences affiliated to Rhodobacteriales

546 (Alphaproteobacteria) were retrieved from PA5 (Figure 6, Table S4). Depending on the

547 dissolved inorganic phosphorous availability, the abundance of bacteria harbouring the gene

548 cluster can vary between as much as $20 \%$ and below $1 \%$ of all bacteria (Martinez, Tyson \&

549 Delong, 2010), indicating that the presence of the C-P lyase provide an advantage in

550 phosphorous limited environments. We could not find a high abundance of this protein complex 
551 in the Arabian Sea OMZ, hence the ability for acquiring phosphorous from Mpn might be less

552 important in this system.

553 In accordance with the absence of marker genes indicative for methane production, only few

554 reads were retrieved that could be affiliated with methane oxidation. For aerobic methane

555 oxidation, we used the marker genes $p m o A$ and $m m o X$ encoding the particulate and soluble

556 methane monooxygenase. In the PA2 dataset, $15 \mathrm{mmoX}$ and $3 \mathrm{pmoA}$-like reads were detected.

557 However, after closer inspection, all $m m o X$ reads showed moderate sequence identity (up to $71 \%$

558 on amino acid level) to homologous toluene monoxygenases. For the pmoA reads, highest

559 identity (68-97\% on amino acid level) was found to the monooxygenase of the SAR324 clade

560 (deltaproteobacteria). Based on 16S rRNA gene abundance, the SAR324 clade was found to

561 belong, besides others, to the dominant bacteria in the Arabian Sea dataset (Figure 1). So far, no

562 enrichment of SAR324 clade bacteria is available and it is not known if this monooxygenase is

563 used for methane or higher alkane oxidation. Whereas the $p m o A$ phylogeny indicates relation to

564 C2-C4 alkane monooxygenases ( $\mathrm{Li}$ et al., 2014), the genomes of SAR324 members suggest the

565 potential for both, $\mathrm{C} 1$ and higher alkane utilization (Sheik, Jain \& Dick, 2014). Nevertheless, not

566 all SAR324 genomes contain the alkane monooxygenase gene cluster (Swan et al., 2011). The

567 PA5 dataset revealed $2 \mathrm{pmoA}$ and $2 \mathrm{mmoX}$-like sequences, again only with moderate sequence

568 identities to known alkane monooxygenases. Consistent with the absence of genes encoding the

569 putative nitric oxide dismutase of NC10 phylum bacteria, we did not find any pmoA genes of

570 these bacteria in the Arabian sea OMZ. Nevertheless, they might be present in a low abundance

571 that could not be retrieved by our approach. Thus, if these bacteria play a role in methane and

572 nitrogen cycling in OMZs, as suggested for the Eastern Pacific OMZ, needs to be investigated in

573 future research (Padilla et al., 2016). In addition, 16S rRNA gene sequences of known aerobic 
574 methanotrophs were nearly absent. Only 3 reads clustering within gammaproteobacterial

575 methanotrophs were present (1 read from PA2 and 2 reads from PA5). Although the overall

576 abundance of hydrocarbon monooxygenase encoding reads is low in the Arabian Sea OMZ

577 dataset, our analysis shows the existence of novel sequence diversity only moderately related to

578 known sequences, that is not captured by currently used PCR primers.

579

580

581

582 Conclusion

583 In this study, we compared the functional diversity in two metagenomes retrieved from the

584 Arabian Sea oxygen minimum zone. Using manually curated reference databases, we screened

585 the datasets for homologues indicative for nitrogen and methane turnover in this ecosystem. We

586 are aware that the presence of genetic potential alone cannot be used to draw conclusions on

587 activity of various processes. However, despite this limitation, the picture that emerges from our

588 analysis is that the vast majority of organisms can contribute to nitrate reduction, probably

589 coupled to degradation of organic matter and release of ammonium (Kalvelage et al., 2015). The

590 nitrite formed by nitrate reduction can be re-oxidized to nitrate in a 'nitrite loop' ultimately

591 resulting in removal of additional organic matter and release of more ammonium. The $n r f$-like

592 nitrite reductase assembled from our dataset is only distantly related to described $n r f$ sequences

593 indicating that a yet unknown organism is responsible for this reaction in the Arabian Sea. The

594 released ammonium can partially be oxidized by a diverse community of microaerophilic

595 archaeal ammonium oxidizers, but in the core of the OMZ, the majority is likely converted by

596 anammox bacteria, which contribute about $5 \%$ to the total abundance at the station PA5. Here, 
597 we could confirm the presence of a low diversity dominated by a Candidatus 'Scalindua 598 arabica'-like anammox species as observed in previous studies (Villanueva et al., 2014, 599 Woebken et al., 2010). Although denitrification was observed as the dominant process in another 600 Arabian Sea study (Ward et al., 2009), our analysis, albeit only based on the genetic potential, 601 does not support this point. Rather, an intricate nitrogen cycle involving many organisms and the 602 exchange of intermediates and connection to other processes, as recently hypothesized for 603 estuary and an aquifer (Hug et al, 2015, Baker et al., 2015) seems likely. The ultimate removal of 604 nitrogen is most likely mediated by anammox. We found no evidence for methane turnover in 605 the Arabian Sea OMZ, however, the metagenomes revealed the presence of new alkane 606 monooxygenase diversity in this ecosystem. 


\section{Acknowledgements}

608 We thank the department of marine organic biogeochemistry and molecular lab facilities of the

609 Royal NIOZ for support. 
610 References

611 Angel R, Matthies D, Conrad R. 2011. Activation of Methanogenesis in Arid Biological Soil

612 Crusts Despite the Presence of Oxygen. Plos One 6: e20453.

613 Babbin AR, Bianchi D, Jayakumar A, Ward BB. 2015. Rapid nitrous oxide cycling in the

$614 \quad$ suboxic ocean. Science 348:1127-1129.

615 Bange HW, Ramesh R, Rapsomanikis S, Andreae MO. 1998. Methane in surface waters of the

616 Arabian Sea. Geophysical Research Letters 25:3547-3550.

617 Beman JM, Popp BN, Francis C a. 2008. Molecular and biogeochemical evidence for ammonia

618 oxidation by marine Crenarchaeota in the Gulf of California. The ISME Journal 2:429-441.

619 Bird C, Wyman M. 2013. Transcriptionally active heterotrophic diazotrophs are widespread in

620 the upper water column of the Arabian Sea. FEMS Microbiology Ecology 84:189-200.

621 Bulow SE, Rich JJ, Naik HS, Pratihary AK, Ward BB. 2010. Denitrification exceeds anammox

622 as a nitrogen loss pathway in the Arabian Sea oxygen minimum zone. Deep-Sea Research

623 Part I: Oceanographic Research Papers 57:384-393.

624 Canfield DE, Stewart FJ, Thamdrup B, De Brabandere L, Dalsgaard T, Delong EF, Revsbech

625 NP, Ulloa O. 2010. A cryptic sulfur cycle in oxygen-minimum-zone waters off the Chilean

626 coast. Science (New York, N.Y.) 330:1375-1378.

627

628

629

630

631

632

633

634

635

636

637

638

639

640

641

642

643

644

645

646

647

648

649

650

651

652

653

Codispoti L a, Brandes J a, Christensen JP, Devol a H, Naqvi SW a, Paerl HW, Yoshinari T. 2001. The oceanic fixed nitrogen and nitrous oxide budgets : Moving targets as we enter the anthropocene? Scientia Marina 65:85-105.

Codispoti L a., Richards F a. 1976. An analysis of the horizontal regime of denitrification in the eastern tropical North Pacific. Limnology and Oceanography 21:379-388.

Daughton CG, Cook AM, Alexander M. 1979. by using standard methods [3]. The enrichment and isolation procedures have been described [4]. 5:91-93.

Deutsch C, Sarmiento JL, Sigman DM, Gruber N, Dunne JP. 2007. Spatial coupling of nitrogen inputs and losses in the ocean. Nature 445:163-167.

Devol a. H, Uhlenhopp a. G, Naqvi SW a., Brandes J a., Jayakumar D a., Naik H, Gaurin S, Codispoti L a., Yoshinari T. 2006. Denitrification rates and excess nitrogen gas concentrations in the Arabian Sea oxygen deficient zone. Deep Sea Research Part I: Oceanographic Research Papers 53:1533-1547.

Dumont MG, Lüke C, Deng Y, Frenzel P. 2014. Classification of pmoA amplicon pyrosequences using BLAST and the lowest common ancestor method in MEGAN . Frontiers in Microbiology 5:34.

Dupont CL, Rusch DB, Yooseph S, Lombardo M-J, Alexander Richter R, Valas R, Novotny M, Yee-Greenbaum J, Selengut JD, Haft DH, Halpern AL, Lasken RS, Nealson K, Friedman R, Craig Venter J. 2012. Genomic insights to SAR86, an abundant and uncultivated marine bacterial lineage. The ISME Journal 6:1186-1199.

Dutilh BE, Huynen MA, Strous M. 2009. Increasing the coverage of a metapopulation consensus genome by iterative read mapping and assembly. Bioinformatics 25:2878-2881.

Dyhrman ST, Chappell PD, Haley ST, Moffett JW, Orchard ED, Waterbury JB, Webb EA. 2006. Phosphonate utilization by the globally important marine diazotroph Trichodesmium. Nature 439:68-71.

Edgar RC. 2010. Supplementary Material - Search and clustering orders of magnitude faster than BLAST. Bioinformatics 26:2460-2461. 
654 Evans PN, Parks DH, Chadwick GL, Robbins SJ, Orphan VJ, Golding SD, Tyson GW. 2015.

655

656

657

658

659

660

661

662

663

664

665

666

667

668

669

670

671

672

673

674

675

676

677

678

679

680

681

682

683

684

685

686

687

688

689

690

691

692

693

694

695

696

697

Methane metabolism in the archaeal phylum Bathyarchaeota revealed by genome-centric metagenomics. 350 .

Field KG, Gordon D, Wright T, Rappé M, Urbach E, Vergin K, Giovannoni SJ. 1997. Diversity and depth-specific distribution of SAR11 cluster rRNA genes from marine planktonic bacteria. Applied and Environmental Microbiology 63:63-70.

Frigaard N-U, Martinez A, Mincer TJ, DeLong EF. 2006. Proteorhodopsin lateral gene transfer between marine planktonic Bacteria and Archaea. Nature 439:847-850.

Fuhrman JA, McCallum K, Davis AA. 1993. Phylogenetic diversity of subsurface marine microbial communities from the Atlantic and Pacific Oceans. Applied and Environmental Microbiology 9:1294-1302.

Füssel J, Lam P, Lavik G, Jensen MM, Holtappels M, Günter M, Kuypers MM. 2012. Nitrite oxidation in the Namibian oxygen minimum zone. The ISME Journal 6:1200-1209.

Gaby JC, Buckley DHA. 2014. A comprehensive aligned nifH gene database: a multipurpose tool for studies of nitrogen-fixing bacteria. Database-Oxford bau001.

Giovannoni SJ, Tripp HJ, Givan S, Podar M, Vergin KL, Baptista D, Bibbs L, Eads J, Richardson TH, Noordewier M, Rappé MS, Short JM, Carrington JC, Mathur EJ. 2005. Genome Streamlining in a Cosmopolitan Oceanic Bacterium. Science 309 :1242-1245.

Glass JB, Kretz CB, Ganesh S, Ranjan P, Seston SL, Buck KN, Landing WM, Morton PL, Moffett JW, Giovannoni SJ, Vergin KL, Stewart FJ. 2015. Meta-omic signatures of microbial metal and nitrogen cycling in marine oxygen minimum zones. Frontiers in Microbiology 6:1-13.

Gordon D a, Giovannoni SJ. 1996. Stratified microbial populations related to Chlorobium and Fibrobacter detected in the Atlantic and Pacific Oceans. Appl. Environ. Microbiol. 62:11711177.

Groffman PM, Altabet M a., Bohlke JK, Butterbach-Bahl K, David MB, Firestone MK, Giblin AE, Kana TM, Nielsen LP, Voyteck M a. 2006. Methods for Measuring Denitrification : Ecological Applications 16:2091-2122.

Gruber N, Sarmiento JL. 1997. Global patterns of marine nitrogen fixation and denitrification. Global Biogeochemical Cycles 11:235.

Hamersley MR, Lavik G, Woebken D, Rattray JE, Lam P, Hopmans EC, Damsté JSS, Krüger S, Graco M, Gutiérrez D, Kuypers MMM. 2007. Anaerobic ammonium oxidation in the Peruvian oxygen minimum zone. Limnol. Oceanogr. 52:923-933.

Huang J, Su Z, Xu Y. 2005. The Evolution of Microbial Phosphonate Degradative Pathways. Journal of Molecular Evolution 61:682-690.

Huson DH, Auch AF, Qi J, Schuster SC. 2007. MEGAN analysis of metagenomic data. Genome Research 17:377-386.

Huson DH, Mitra S, Ruscheweyh H-J, Wever N, Schuster SC. 2011. Integrative analysis of environmental sequences using MEGAN4. Genome Research 21:1552-1560.

Iverson V, Morris RM, Frazar CD, Berthiaume CT, Morales RL, Armbrust EV. 2012. Untangling Genomes from Metagenomes: Revealing an Uncultured Class of Marine Euryarchaeota. Science $335: 587-590$.

Jayakumar D a., Naqvi SW a, Narvekar P V., George MD. 2001. Methane in coastal and offshore waters of the Arabian Sea. Marine Chemistry 74:1-13. 
698

699

700

701

702

703

704

705

706

707

708

709

710

711

712

713

714

715

716

717

718

719

720

721

722

723

724

725

726

727

728

729

730

731

732

733

734

735

736

737

738

739

740

741

Jayakumar DA, Francis C a., Naqvi SW a., Ward BB. 2004. Diversity of nitrite reductase genes (nirS) in the denitrifying water column of the coastal Arabian Sea. Aquatic Microbial Ecology 34:69-78.

Jayakumar A, Al-Rshaidat MMD, Ward BB, Mulholland MR. 2012. Diversity, distribution, and expression of diazotroph nifH genes in oxygen-deficient waters of the Arabian Sea. FEMS Microbiology Ecology 82:597-606.

Jensen MM, Lam P, Revsbech NP, Nagel B, Gaye B, Jetten MS, Kuypers MM. 2011. Intensive nitrogen loss over the Omani Shelf due to anammox coupled with dissimilatory nitrite reduction to ammonium. The ISME Journal 5:1660-1670.

Kalvelage T, Jensen MM, Contreras S, Revsbech NP, Lam P, Günter M, LaRoche J, Lavik G, Kuypers MMM. 2011. Oxygen sensitivity of anammox and coupled N-cycle processes in oxygen minimum zones. PLOS ONE 6:e29299.

Kalvelage T, Lavik G, Jensen MM, Revsbech NP, Löscher C, Schunck H, Desai DK, Hauss H, Kiko R, Holtappels M, LaRoche J, Schmitz R a, Graco MI, Kuypers MMM. 2015. Aerobic Microbial Respiration In Oceanic Oxygen Minimum Zones. PloS one 10:e133526.

Karl DM, Beversdorf L, Bjorkman KM, Church MJ, Martinez A, Delong EF. 2008. Aerobic production of methane in the sea. Nature Geosci 1:473-478.

Knittel K, Boetius A. 2009. Anaerobic Oxidation of Methane: Progress with an Unknown Process. Annual Review of Microbiology 63:311-334.

Kozlowski JA, Stieglmeier M, Schleper C, Klotz MG, Stein LY. 2016. Pathways and key intermediates required for obligate aerobic ammonia-dependent chemolithotrophy in bacteria and Thaumarchaeota. The ISME Journal doi:10.1038/ismej.2016.2

Kuypers MMM, Sliekers AO, Lavik G, Schmid M, Jorgensen BB, Kuenen JG, Sinninghe Damste JS, Strous M, Jetten MSM. 2003. Anaerobic ammonium oxidation by anammox bacteria in the Black Sea. Nature 422:608-611.

Kuypers MMM, Kuypers MMM, Lavik G, Lavik G, Woebken D, Woebken D, Schmid M, Schmid M, Fuchs BM, Fuchs BM, Amann R, Amann R, Jørgensen BB, Jørgensen BB, Jetten MSM, Jetten MSM. 2005. Massive nitrogen loss from the Benguela upwelling system through anaerobic ammonium oxidation. Proceedings of the National Academy of Sciences of the United States of America 102:6478-83.

Lam P, Lavik G, Jensen MM, van de Vossenberg J, Schmid M, Woebken D, Gutiérrez D, Amann R, Jetten MSM, Kuypers MMM. 2009. Revising the nitrogen cycle in the Peruvian oxygen minimum zone. Proceedings of the National Academy of Sciences of the United States of America 106:4752-4757.

Lam P, Kuypers MMM. 2011. Microbial Nitrogen Cycling Processes in Oxygen Minimum Zones. Annual Review of Marine Science 3:317-345.

Lavik G, Stuhrmann T, Bruchert V, Van der Plas A, Mohrholz V, Lam P, Muszmann M, Fuchs BM, Amann R, Lass U, Kuypers MMM. 2009. Detoxification of sulphidic African shelf waters by blooming chemolithotrophs. Nature 457:581-584.

Li M, Jain S, Baker BJ, Taylor C, Dick GJ. 2014. Novel hydrocarbon monooxygenase genes in the metatranscriptome of a natural deep-sea hydrocarbon plume. Environmental Microbiology 16:60-71.

Lipschultz F, Wofsy SC, Ward BB, Codispoti L a, Friedrich G, Elkins JW. 1990. Bacterial transformations of inorganic nitrogen in the oxygen-deficient waters of the Eastern Tropical 
742

743

744

745

746

747

748

749

750

751

752

753

754

755

756

757

758

759

760

761

762

763

764

765

766

767

768

769

770

771

772

773

774

775

776

777

778

779

780

781

782

South Pacific Ocean. Deep Sea Research Part A. Oceanographic Research Papers 37:1513-1541.

Ludwig W, Strunk O, Westram R, Richter L, Meier H, Yadhukumar, Buchner A, Lai T, Steppi S, Jobb G, Förster W, Brettske I, Gerber S, Ginhart AW, Gross O, Grumann S, Hermann S, Jost R, König A, Liss T, Lüßmann R, May M, Nonhoff B, Reichel B, Strehlow R, Stamatakis A, Stuckmann N, Vilbig A, Lenke M, Ludwig T, Bode A, Schleifer K-H. 2004. ARB: a software environment for sequence data. Nucleic Acids Research 4:1363-1371.

Lücker S, Wagner M, Maixner F, Pelletier E, Koch H, Vacherie B, Rattei T, Damste JSS, Spieck E, Le Paslier D, Daims H. 2010. A Nitrospira metagenome illuminates the physiology and evolution of globally important nitrite-oxidizing bacteria. Proceedings of the National Academy of Sciences 107:13479-13484.

Martinez A, Tyson GW, DeLong EF. 2010. Widespread known and novel phosphonate utilization pathways in marine bacteria revealed by functional screening and metagenomic analyses. Environmental Microbiology 12:222-238.

Metcalf WW, Griffin BM, Cicchillo RM, Gao J, Janga SC, Cooke HA, Circello BT, Evans BS, Martens-Habbena W, Stahl DA, van der Donk WA. 2012. Synthesis of Methylphosphonic Acid by Marine Microbes: A Source for Methane in the Aerobic Ocean. Science 337:11041107.

Metcalf WW, Wanner BL. 1993. Mutational analysis of an Escherichia coli fourteen-gene operon for phosphonate degradation, using TnphoA' elements. Journal of Bacteriology 175:3430-3442.

Molina V, Ulloa O, Farías L, Urrutia H, Ramírez S, Junier P, Witzel K-P. 2007. Ammoniaoxidizing beta-proteobacteria from the oxygen minimum zone off northern Chile. Applied and environmental microbiology 73:3547-55.

Morris RM, Vergin KL, Cho J-C, Rappé MS, Carlson C a., Giovannoni SJ. 2005. Temporal and spatial response of bacterioplankton lineages to annual convective overturn at the Bermuda Atlantic Time-series Study site. Limnology and Oceanography 50:1687-1696.

Newell SE, Babbin AR, Jayakumar A, Ward BB. 2011. Ammonia oxidation rates and nitrification in the Arabian Sea. Global Biogeochemical Cycles 25:1-10.

Nobu MK, Narihiro T, Rinke C, Kamagata Y, Tringe SG, Woyke T, Liu W-T. 2015. Microbial dark matter ecogenomics reveals complex synergistic networks in a methanogenic bioreactor. The ISME Journal 9:1710-1722.

Orsi WD, Smith JM, Wilcox HM, Swalwell JE, Carini P, Worden AZ, Santoro AE. 2015. Ecophysiology of uncultivated marine euryarchaea is linked to particulate organic matter. The ISME Journal 9:1747-1763.

Owens NJP, Law CS, Mantoura RFC, Burkill PH, Llewellyn CA. 1991. Methane flux to the atmosphere from the Arabian Sea. Nature 354:293-296.

Pester M, Rattei T, Flechl S, Gröngröft A, Richter A, Overmann J, Reinhold-Hurek B, Loy A, Wagner M. 2012. amoA-based consensus phylogeny of ammonia-oxidizing archaea and deep sequencing of amoA genes from soils of four different geographic regions . Environmental Microbiology 14:525-539. 
783

784

785

786

787

788

789

790

791

792

793

794

795

796

797

798

799

800

801

802

803

804

805

806

807

808

809

810

811

812

813

814

815

816

817

818

819

820

821

822

823

824

825

826

827

Padilla CC, Bristow LA, Sarode N, Garcia-Robledo E, Gómez Ramírez E, Benson CR, Bourbonnais A, Altabet MA, Girguis PR, Thamdrup B, Stewart FJ. 2016. NC10 bacteria in marine oxygen minimum zones. The ISME Journal. doi:10.1038/ismej.2015.262.

Pitcher A, Villanueva L, Hopmans EC, Schouten S, Reichart G-J, Sinninghe Damsté JS. 2011. Niche segregation of ammonia-oxidizing archaea and anammox bacteria in the Arabian Sea oxygen minimum zone. The ISME Journal 5:1896-1904.

Pruesse E, Peplies J, Glockner FO. 2012. SINA: Accurate high-throughput multiple sequence alignment of ribosomal RNA genes. Bioinformatics 28:1823-1829.

Quast C, Pruesse E, Yilmaz P, Gerken J, Schweer T, Yarza P, Peplies J, Glockner FO. 2013. The SILVA ribosomal RNA gene database project: improved data processing and web-based tools. Nucleic Acids Research 41:D590-D596.

Rappe MS, Connon SA, Vergin KL, Giovannoni SJ. 2002. Cultivation of the ubiquitous SAR11 marine bacterioplankton clade. Nature 418:630-633.

Rasko D a, Myers GS a, Ravel J. 2005. Visualization of comparative genomic analyses by BLAST score ratio. BMC bioinformatics 6:2.

Redfield AC, Ketchum BH, Richards FA. 1963. The influence of organisms on the composition of sea-water. p. 26- 77. In M. N. Hill [ed.], The sea, v. 2. Interscience.

Revsbech NP, Larsen LH, Gundersen J, Dalsgaard T, Ulloa O, Thamdrup B. 2009. Determination of ultra-low oxygen concentrations in oxygen minimum zones by the STOX sensor. Limnology and Oceanography: Methods 7:371-381.

Rinke C, Schwientek P, Sczyrba A, Ivanova NN, Anderson IJ, Cheng J-F, Darling AE, Malfatti S, Swan BK, Gies E a, Dodsworth J a, Hedlund BP, Tsiamis G, Sievert SM, Liu W-T, Eisen J a, Hallam SJ, Kyrpides NC, Stepanauskas R, Rubin EM, Hugenholtz P, Woyke T. 2013. Insights into the phylogeny and coding potential of microbial dark matter. Nature 499:431437.

Russ L, Speth DR, Jetten MSM, Op den Camp HJM, Kartal B. 2014. Interactions between anaerobic ammonium and sulfur-oxidizing bacteria in a laboratory scale model system. Environmental Microbiology 16:3487-3498.

Sansone F, Popp B. 2001. Highly elevated methane in the eastern tropical North Pacific and associated isotopically enriched fluxes to the atmosphere. Geophysical ... 28:4567-4570.

Santoro AE, Dupont CL, Richter RA, Craig MT, Carini P, McIlvin MR, Yang Y, Orsi WD, Moran DM, Saito MA. 2015. Genomic and proteomic characterization of "Candidatus Nitrosopelagicus brevis": An ammonia-oxidizing archaeon from the open ocean. Proceedings of the National Academy of Sciences 112:1173-1178.

Santoro a E, Casciotti KL, Francis C a. 2010. Activity, abundance and diversity of nitrifying archaea and bacteria in the central California Current. Environmental Microbiology 12:1989-2006.

Schouten S, Pitcher A, Hopmans EC, Villanueva L, van Bleijswijk J, Sinninghe Damsté JS. 2012. Intact polar and core glycerol dibiphytanyl glycerol tetraether lipids in the Arabian Sea oxygen minimum zone: I. Selective preservation and degradation in the water column and consequences for the TEX86. Geochimica et Cosmochimica Acta 98:228-243.

Sheik CS, Jain S, Dick GJ. 2014. Metabolic flexibility of enigmatic SAR324 revealed through metagenomics and metatranscriptomics. Environmental Microbiology 16:304-317.

Sievers F, Wilm A, Dineen D, Gibson TJ, Karplus K, Li W, Lopez R, McWilliam H, Remmert M, Soding J, Thompson JD, Higgins DG. 2011. Fast, scalable generation of high-quality 
828

829

830

831

832

833

834

835

836

837

838

839

840

841

842

843

844

845

846

847

848

849

850

851

852

853

854

855

856

857

858

859

860

861

862

863

864

865

866

867

868

869

870

871

protein multiple sequence alignments using Clustal Omega. Molecular Systems Biology 7:539.

Speth DR, Russ L, Kartal B, Camp JM Den, Dutilh BE, Jetten SM. 2015. Draft Genome Sequence of Anammox Bacterium "Candidatus Scalindua brodae", Obtained Using Differential Coverage Binning of Sequencing Data from Two Reactor Enrichments. Genome announcements 4:1-2.

Stahl DA, de la Torre JR. 2012. Physiology and Diversity of Ammonia-Oxidizing Archaea. Annual Review of Microbiology 66:83-101.

Stewart FJ, Ulloa O, DeLong EF. 2012. Microbial metatranscriptomics in a permanent marine oxygen minimum zone. Environmental microbiology 14:23-40.

Swan BK, Martinez-Garcia M, Preston CM, Sczyrba A, Woyke T, Lamy D, Reinthaler T, Poulton NJ, Masland EDP, Gomez ML, Sieracki ME, DeLong EF, Herndl GJ, Stepanauskas R. 2011. Potential for Chemolithoautotrophy Among Ubiquitous Bacteria Lineages in the Dark Ocean. Science 333:1296-1300.

Tavormina PL, Ussler W, Steele J a., Connon S a., Klotz MG, Orphan VJ. 2013. Abundance and distribution of diverse membrane-bound monooxygenase (Cu-MMO) genes within the Costa Rica oxygen minimum zone. Environmental Microbiology Reports 5:414-423.

Thamdrup B, Dalsgaard T, Jensen MM, Ulloa O, Farías L, Escribano R. 2006. Anaerobic ammonium oxidation in the oxygen-deficient waters off northern Chile. Limnology and Oceanography 51:2145-2156.

Thamdrup B, Dalsgaard T, Revsbech NP. 2012. Widespread functional anoxia in the oxygen minimum zone of the Eastern South Pacific. Deep Sea Research Part I: Oceanographic Research Papers 65:36-45.

Upstill-Goddard RC, Barnes J, Owens NJP. 1999. Nitrous oxide and methane during the 1994 SW monsoon in the Arabian Sea/northwestern Indian Ocean. Journal of Geophysical Research 104:30067.

Vergin KL, Beszteri B, Monier A, Thrash JC, Temperton B, Treusch AH, Kilpert F, Worden AZ, Giovannoni SJ. 2013. High-resolution SAR11 ecotype dynamics at the Bermuda Atlantic Time-series Study site by phylogenetic placement of pyrosequences. The ISME journal 7:1322-32.

Villanueva L, Speth DR, van Alen T, Hoischen A, Jetten MSM. 2014. Shotgun metagenomic data reveals significant abundance but low diversity of "Candidatus Scalindua" marine anammox bacteria in the Arabian Sea oxygen minimum zone. Frontiers in Microbiology $5: 1-9$.

Villanueva L, Schouten S, Sinninghe Damsté JS. 2014. Depth-related distribution of a key gene of the tetraether lipid biosynthetic pathway in marine Thaumarchaeota. Environmental microbiology 6:1-32.

Van de Vossenberg J, Woebken D, Maalcke WJ, Wessels HJCT, Dutilh BE, Kartal B, JanssenMegens EM, Roeselers G, Yan J, Speth D, Gloerich J, Geerts W, van der Biezen E, Pluk W, Francoijs K-J, Russ L, Lam P, Malfatti SA, Tringe SG, Haaijer SCM, Op den Camp HJM, Stunnenberg HG, Amann R, Kuypers MMM, Jetten MSM. 2013. The metagenome of the marine anammox bacterium "Candidatus Scalindua profunda" illustrates the versatility of this globally important nitrogen cycle bacterium. Environmental Microbiology 15:12751289. 
872 Walsh DA, Zaikova E, Howes CG, Song YC, Wright JJ, Tringe SG, Tortell PD, Hallam SJ. 873 2009. Metagenome of a Versatile Chemolithoautotroph from Expanding Oceanic Dead $874 \quad$ Zones. Science $326: 578-582$.

875 Ward BB, Devol AH, Rich JJ, Chang BX, Bulow SE, Naik H, Pratihary A, Jayakumar A. 2009.

876 Denitrification as the dominant nitrogen loss process in the Arabian Sea. Nature 461:78-81.

877 White a. E, Karl DM, Björkman K, Beversdorf LJ, Letelier RM. 2010. Production of organic 878 matter by Trichodesmium IMS101 as a function of phosphorus source. Limnology and 879 Oceanography 55:1755-1767.

880 Woebken D, Lam P, Kuypers MMM, Naqvi SW a, Kartal B, Strous M, Jetten MSM, Fuchs BM, 881 Amann RI. 2008. A microdiversity study of anammox bacteria reveals a novel Candidatus Scalindua phylotype in marine oxygen minimum zones. Environmental Microbiology 10:3106-3119.

Wright JJ, Konwar KM, Hallam SJ. 2012. Microbial ecology of expanding oxygen minimum zones. Nature Reviews Microbiology 10:381-394.

Zeigler Allen L, Allen EE, Badger JH, McCrow JP, Paulsen IT, Elbourne LDH, Thiagarajan M, Rusch DB, Nealson KH, Williamson S, Venter JC, Allen AE. 2012. Influence of nutrients and currents on the genomic composition of microbes across an upwelling mosaic. The ISME Journal 6:1403-1414. 
$890 \quad$ Figure legends

891 Figure 1. Overview of microbial 16S rRNA gene diversity detected in the upper limit (station

892 PA2) and the anoxic core (station PA5) of the Arabian Sea oxygen minimum zone. Sequence

893 reads are shown as percentage of total 16S rRNA read counts. Only phylogenetic groups

894 accounting for more than $1 \%$ of the total community in at least one of the two datasets are listed.

895 Figure 2. Phylogenetic inference of thaumarchaeal 16S rRNA and ammonia monooxygenase

896 (amoA) gene contigs assembled from the OMZ metagenomes. The trees were calculated using 897 the Neighbor Joining algorithm and based on 1225 nucleotide positions for the 16S rRNA gene 898 (left) and 144 deduced amino acid positions for the amoA gene (right).

899 Figure 3. Phylogenetic inference of Scalindua-related 16S rRNA and hydrazine dehydrogenase $900 h d h$ gene contigs assembled from the OMZ metagenomes. The tree were calculated using the 901 Neighbor Joining algorithm and based on 1388 nucleotide positions for the 16S rRNA gene (left) 902 and 180 deduced amino acid positions for the $h d h$ gene (right).

903 Figure 4. Nitrogen cycling potential in the Arabian Sea oxygen minimum zone. Read 904 abundances were normalized according to gene length and total read abundance in the 905 metagenome dataset. Normalized abundances are shown as proportion (blue) of total normalized 906 rров (RNA polymerase) gene abundance (grey). The description of all marker genes and 907 methane and nitrogen cycling processes is given in Table 1.

908 Figure 5. Phylogenetic inference of nitrite oxidoreductase ( $x x \mathrm{r} A$ ) gene sequences from the OMZ 909 metagenomes. The tree was calculated using the Neighbor Joining algorithm and based on 3209

910 nucleotide positions. Bootstrap values represent 1000 replicates.

911 Figure 6. Methane cycling potential in the Arabian Sea oxygen minimum zone. Read 912 abundances were normalized according to gene length and total read abundance in the 913 metagenome dataset. Normalized abundances are shown as proportion (blue) of total normalized $914 r$ rров (RNA polymerase) gene abundance (grey). Original read abundances are given in addition

915 below or above the pie charts. HEP: 2-hydroxyethylphosphonate. Mpn: Methylphosphonate. All 916 nitrogen and methane cycling marker genes are described in Table 1. 


\section{Figure 1 (on next page)}

Overview of microbial $16 \mathrm{~S}$ rRNA gene diversity in the Arabian Sea oxygen minimum zone

Overview of microbial 16S rRNA gene diversity detected in the suboxic zone (station PA2) and the anoxic core (station PA5) of the Arabian Sea oxygen minimum zone. Sequence reads are shown as percentage of total 16S rRNA read counts. Only phylogenetic groups accounting for more than $1 \%$ of the total community in at least one of the two datasets are listed. 


\begin{tabular}{|c|c|c|c|c|c|}
\hline \multicolumn{4}{|c|}{ Taxonomy } & PA2 & PA5 \\
\hline \multirow{10}{*}{ 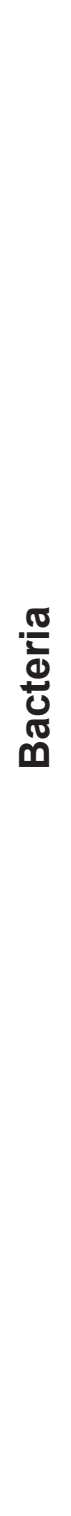 } & \multirow{3}{*}{ 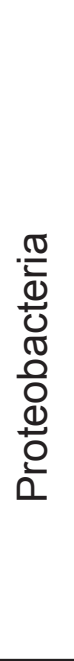 } & Alpha & $\begin{array}{l}\text { SAR11 } \\
\text { Rhodobacteriacaea } \\
\text { Rhodospirillales }\end{array}$ & $\begin{array}{r}14.3 \\
1.5 \\
1.4\end{array}$ & $\begin{array}{l}8.1 \\
0.5 \\
4.2\end{array}$ \\
\hline & & Gamma & $\begin{array}{l}\text { Alteromonadales } \\
\text { SAR86 } \\
\text { SUP05 and alike } \\
\text { Salinisphaeraceae } \\
\text { E01-9C-26 }\end{array}$ & $\begin{array}{l}1.9 \\
7.9 \\
2.9 \\
1.6 \\
0.5\end{array}$ & $\begin{array}{l}1.1 \\
1.5 \\
2.7 \\
1.9 \\
1.6\end{array}$ \\
\hline & & Delta & SAR324 & 5.0 & 3.1 \\
\hline & \multicolumn{2}{|c|}{ Bacteriodetes } & Flavobacteriales & 2.0 & 0.5 \\
\hline & \multicolumn{2}{|c|}{ Planctomycetes } & $\begin{array}{l}\text { Brocadiaceae } \\
\text { Phycisphaerae }\end{array}$ & $\begin{array}{l}<0.1 \\
<0.1\end{array}$ & $\begin{array}{l}5.2 \\
1.1\end{array}$ \\
\hline & \multicolumn{2}{|c|}{ Verrucomicrobia } & Arctic97B-4 & 1.1 & 0.2 \\
\hline & \multicolumn{2}{|c|}{ Deferribacteres } & SAR406 & 8.5 & 19.9 \\
\hline & \multicolumn{2}{|c|}{ Nitrospinae } & Nitrospina & 1.4 & 2.7 \\
\hline & \multicolumn{2}{|c|}{ Actinobacteria } & Acidimicrobia & 3.2 & 2.4 \\
\hline & \multicolumn{2}{|c|}{ Chloroflexi } & $\begin{array}{l}\text { SAR202 } \\
\text { Dehalococcoidia }\end{array}$ & $\begin{array}{c}0.8 \\
0\end{array}$ & $\begin{array}{l}2.4 \\
1.6\end{array}$ \\
\hline \multirow{2}{*}{$\begin{array}{l}\frac{\pi}{0} \\
\frac{d}{\pi} \\
\frac{1}{0} \\
\frac{1}{4}\end{array}$} & \multicolumn{2}{|c|}{ Thaumarchaeota } & Marine Group I & 14.0 & 3.3 \\
\hline & \multicolumn{2}{|c|}{ Euryarchaeota } & $\begin{array}{l}\text { Marine Group II } \\
\text { Marine Group III } \\
\text { Haloarchaea }\end{array}$ & $\begin{array}{c}7.5 \\
1.4 \\
0\end{array}$ & $\begin{array}{l}0.4 \\
0.5 \\
3.8\end{array}$ \\
\hline \multicolumn{4}{|c|}{$\begin{array}{l}\text { Peer) reviewing PSF L(2015:11:7866:1:0:NEW 14 Mar 2016) } \\
\text { Sum of remaining rare taxa }\end{array}$} & 23.0 & 27.6 \\
\hline
\end{tabular}


Figure 2 (on next page)

Phylogenetic inference of thaumarchaeal contigs assembled from the OMZ metagenomes.

The trees were calculated using the Neighbor Joining algorithm and based on 1225

nucleotide positions for the 16S rRNA gene (left) and 144 deduced amino acid positions for the ammonia monooxygenase encoding gene (amoA) (right). 
16S rRNA

amoA

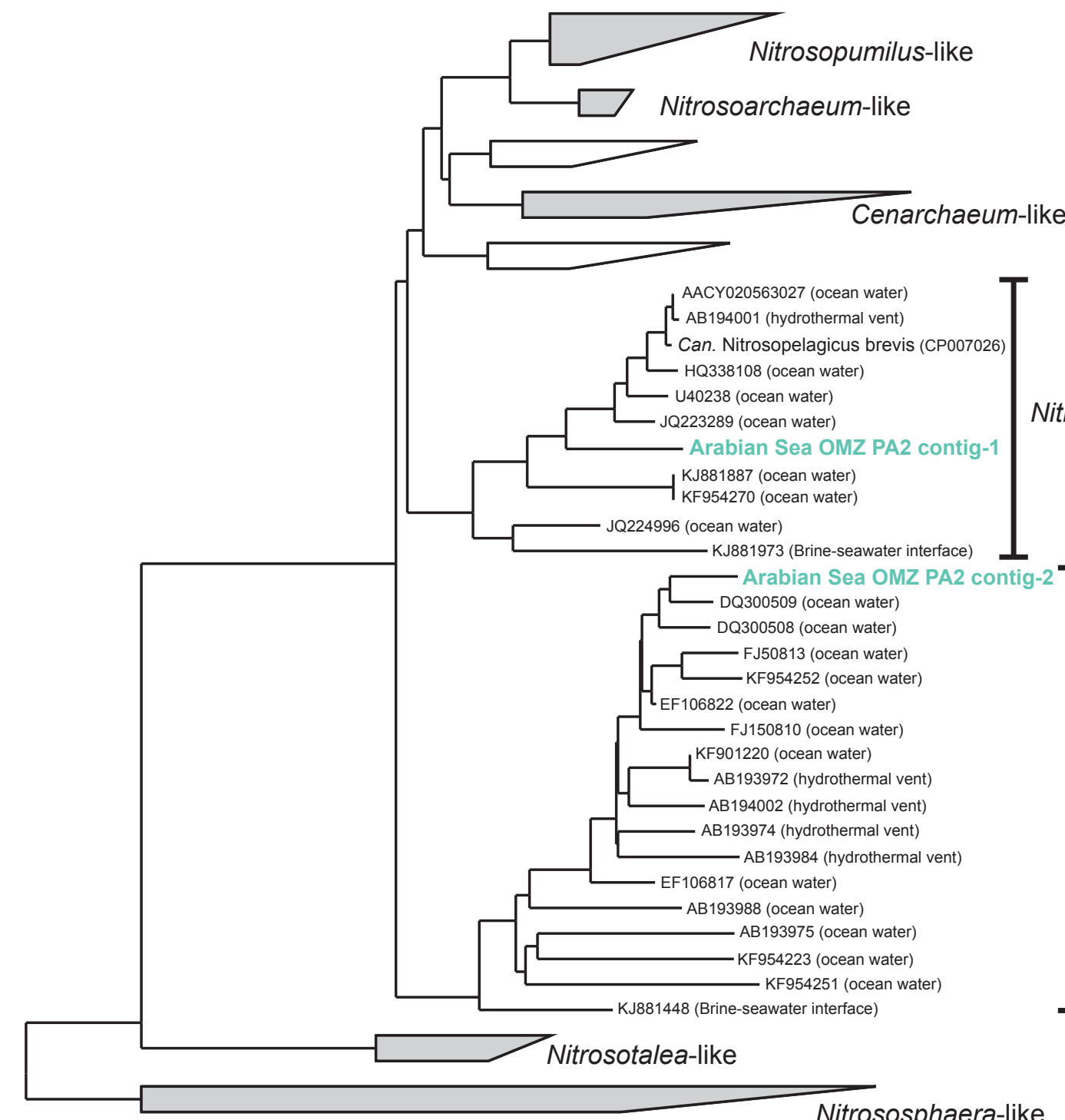

Nitrososphaera-like

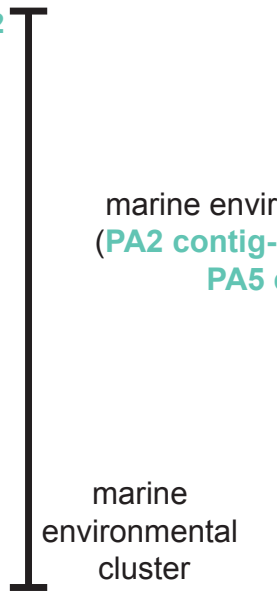

cluster
Nitrosopumilus-like

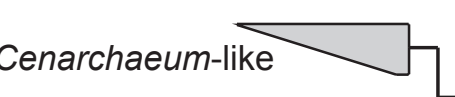

Nitrosoarchaeum limnia SFB1-like $P$

Nitrosoarchaeum-related

(PA2 contig-3)

Nitrosoarchaeum-like

(PA2 contig-4)

Nitrosopelagicus-like
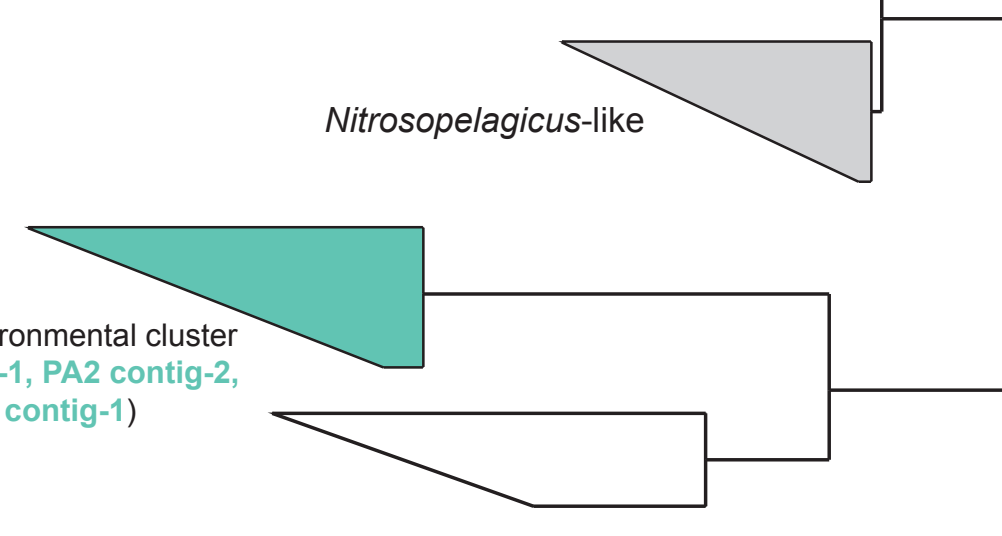

Nitrosotalea-like

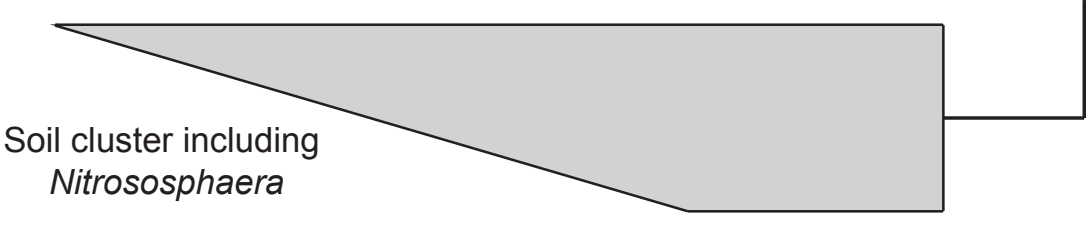


Figure 3 (on next page)

Phylogenetic inference of Scalindua-related contigs assembled from the OMZ metagenomes.

The tree were calculated using the Neighbor Joining algorithm and based on 1388 nucleotide positions for the 16S rRNA gene (left) and 180 deduced amino acid positions for the hydrazine dehydrogenase encoding gene (hdh) (right). 

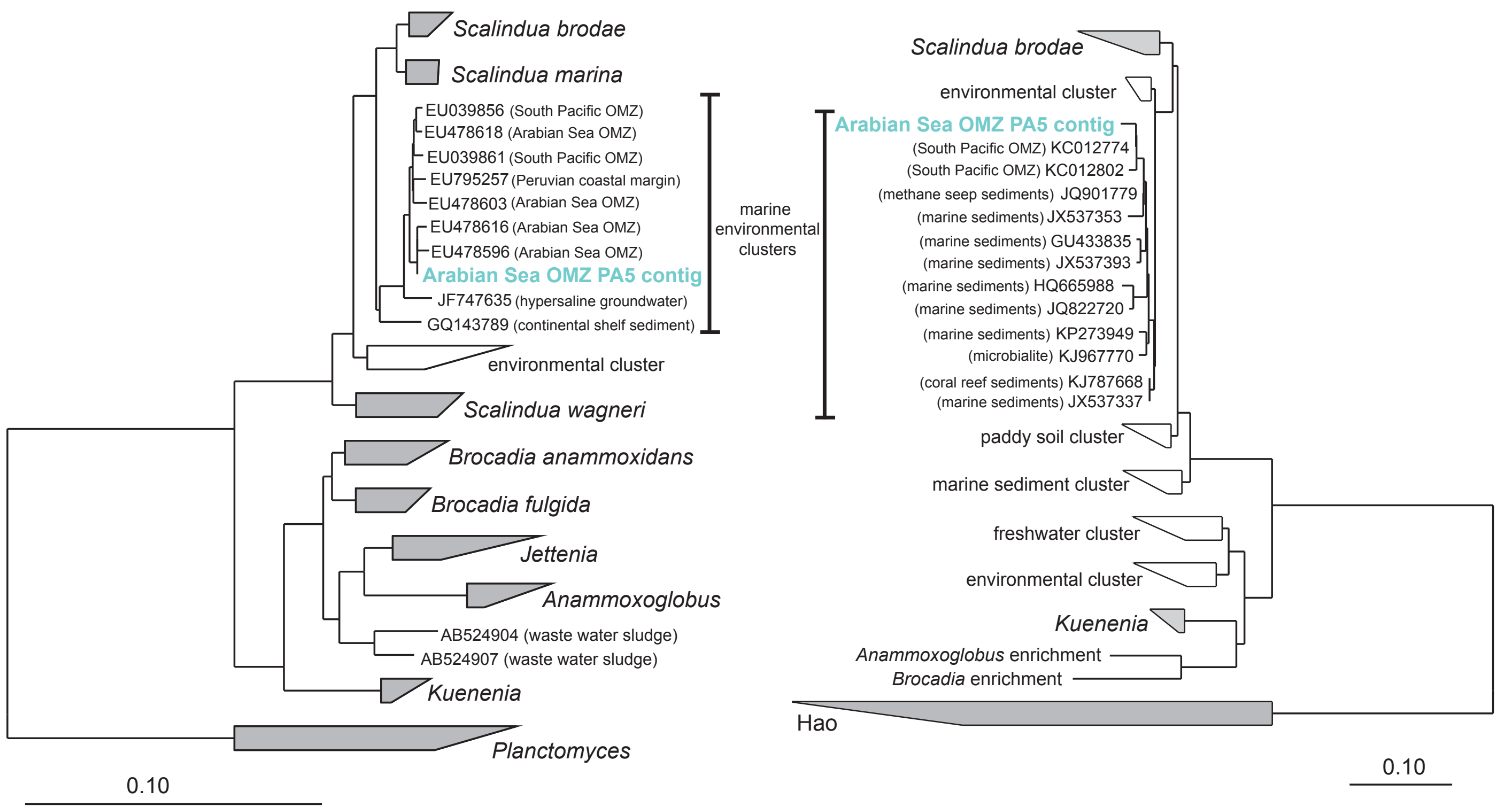
Figure 4 (on next page)

Nitrogen cycling potential in the Arabian Sea oxygen minimum zone.

Read abundances were normalized according to gene length and total read abundance in the metagenome dataset. Normalized abundances are shown as proportion (blue) of total normalized rpoB (RNA polymerase) gene abundance (grey). The description of all marker genes and methane and nitrogen cycling processes is given in Table 1. 


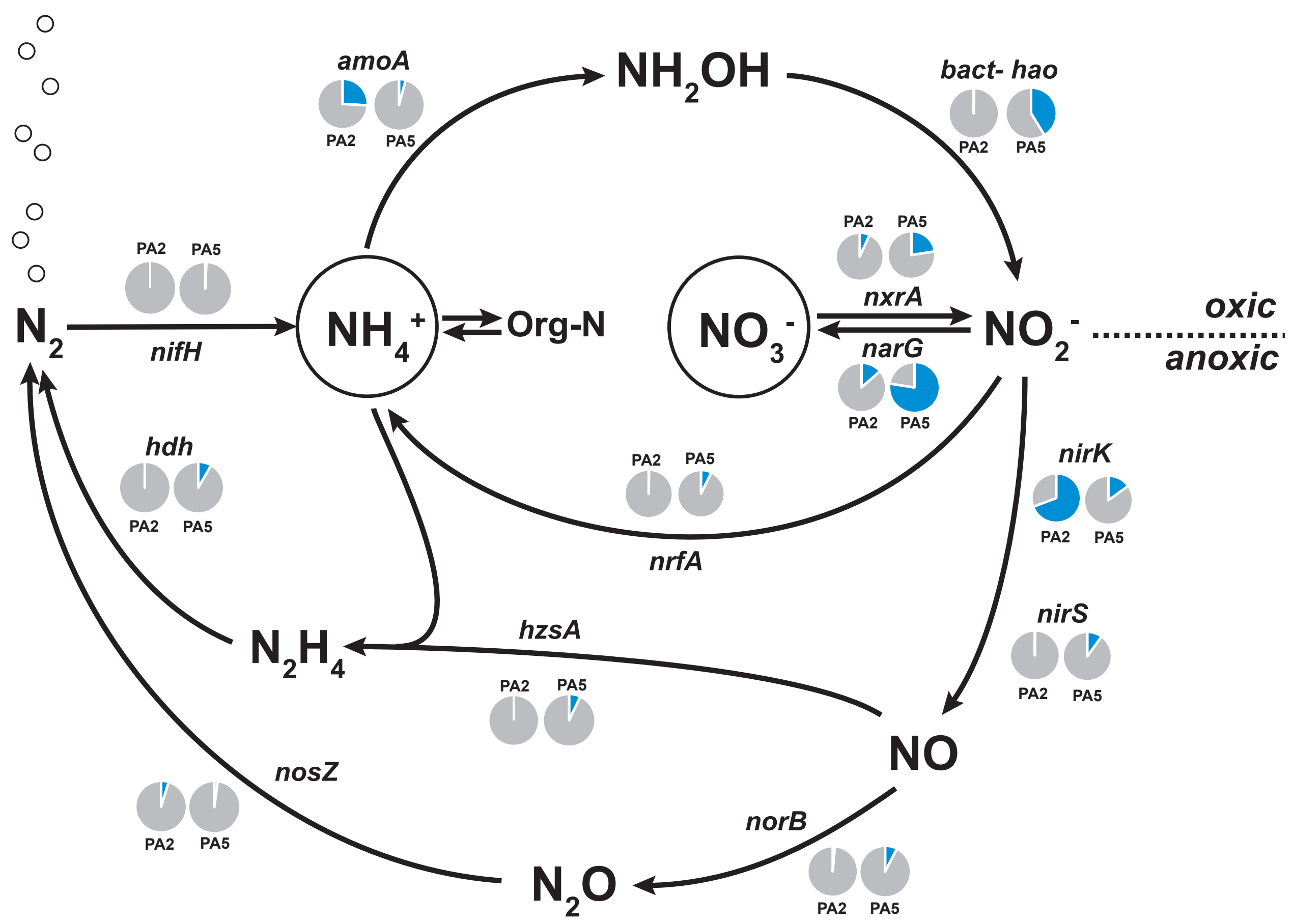


Figure $\mathbf{5}$ (on next page)

Phylogenetic inference of $n x r A$ sequences from the OMZ metagenomes.

The tree was calculated using the Neighbor Joining algorithm and based on 3209 nucleotide positions. Bootstrap values represent 1000 replicates. 

Figure $\mathbf{6}$ (on next page)

Methane cycling potential in the Arabian Sea oxygen minimum zone.

Read abundances were normalized according to gene length and total read abundance in the metagenome dataset. Normalized abundances are shown as proportion (blue) of total normalized rpoB (RNA polymerase) gene abundance (grey). Original read abundances are given in addition below or above the pie charts. HEP: 2-hydroxyethylphosphonate. Mpn: Methylphosphonate. The description of all nitrogen and methane cycling marker genes is given in Table 1. 

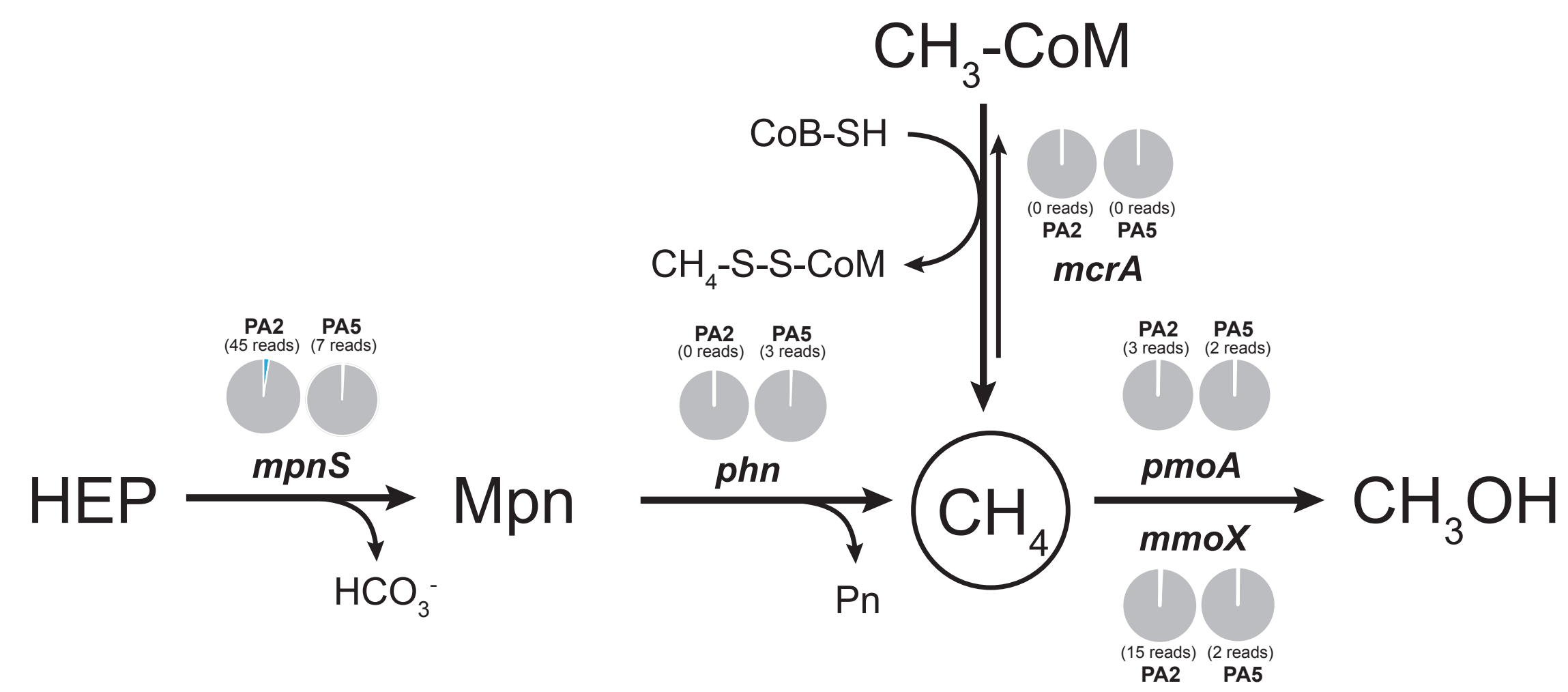


\section{Table $\mathbf{1}$ (on next page)}

Overview of nitrogen and methane cycle marker genes and BLAST score ratio cut-off value used for removal of false positive BLAST hits.

See Figure $\mathrm{S} 2$ for a graphical overview of the bit-score ratio analysis pipeline. DNRA:

dissimilatory nitrite reduction to ammonia. Anammox: anaerobic ammonia oxidation. 
1 Table 1. Overview of nitrogen and methane cycle marker genes and BLAST score ratio cut-off value used 2 for removal of false positive BLAST hits. See Figure S2 for a graphical overview of the bit-score ratio 3 analysis pipeline. DNRA: dissimilatory nitrite reduction to ammonia. Anammox: anaerobic ammonia 4 oxidation.

\begin{tabular}{|c|c|c|c|}
\hline Process & Enzyme name & $\begin{array}{l}\text { Gene } \\
\text { abbreviation }\end{array}$ & $\begin{array}{l}\text { BLAST score } \\
\text { ratio cutoff } \\
\text { (PA2 / PA5) }\end{array}$ \\
\hline Nitrogen fixation & nitrogenase & nifH & \# / \# \\
\hline \multirow[t]{3}{*}{ Nitrification } & $\begin{array}{l}\text { ammonium } \\
\text { monooxygenase }\end{array}$ & $a m o A$ & \# / \# \\
\hline & $\begin{array}{l}\text { hydroxylamine } \\
\text { oxidoreductase }\end{array}$ & hao & \#/ 0.75 \\
\hline & $\begin{array}{l}\text { nitrate:nitrite } \\
\text { oxidoreductase }\end{array}$ & $n \times r A$ & $0.85^{*} / 0.85^{\star}$ \\
\hline $\begin{array}{l}\text { Denitrification/DNRA/ } \\
\text { anammox }\end{array}$ & nitrate reductase & narG & $0.5 / 0.5$ \\
\hline \multirow[t]{4}{*}{ Denitrification } & $\begin{array}{l}\text { copper nitrite } \\
\text { reductase }\end{array}$ & nirk & $0.55 / 0.55$ \\
\hline & $\begin{array}{l}\text { heme } c d 1 \text { nitrite } \\
\text { reductase }\end{array}$ & nirs & \#/ 0.6 \\
\hline & nitric oxide reductase & norB / norZ & $0.8 / 0.8$ \\
\hline & $\begin{array}{l}\text { nitrous oxide } \\
\text { reductase }\end{array}$ & nosZ & $0.8 / 0.75$ \\
\hline DNRA & $\begin{array}{l}\text { cytochrome c nitrite } \\
\text { reductase }\end{array}$ & $n r f A$ & \# / \# \\
\hline \multirow[t]{2}{*}{ anammox } & hydrazine synthase & $h z s A$ & \#/ 0.75 \\
\hline & $\begin{array}{l}\text { hydrazine } \\
\text { dehydrogenase }\end{array}$ & $h d h$ & $* * / * *$ \\
\hline $\begin{array}{l}\text { Methanogenesis/anaero } \\
\text { bic methane oxidation }\end{array}$ & $\begin{array}{l}\text { methyl-coenzyme M } \\
\text { reductase }\end{array}$ & mcrA & \# / \# \\
\hline \multirow[t]{2}{*}{$\begin{array}{l}\text { Aerobic methane } \\
\text { oxidation }\end{array}$} & $\begin{array}{l}\text { soluble methane } \\
\text { monooxygenase }\end{array}$ & $\operatorname{mmoX}$ & \# / \# \\
\hline & $\begin{array}{l}\text { particulate methane } \\
\text { monooxygenase }\end{array}$ & $p m o A$ & \# / \# \\
\hline $\begin{array}{l}\text { Methylphosphonate } \\
\text { production }\end{array}$ & $\begin{array}{l}\text { methylphosphonate } \\
\text { synthase }\end{array}$ & mpns & \# / \# \\
\hline
\end{tabular}




\begin{tabular}{llll}
\hline $\begin{array}{l}\text { Methylphosphonate } \\
\text { cleavage }\end{array}$ & C-P lyase & phnGHI & $\# / \#$ \\
\hline
\end{tabular}

5 \# manually checked

6 * subset of narG hits, ${ }^{* *}$ subset of hao hits after mapping against Scalindua hdh 